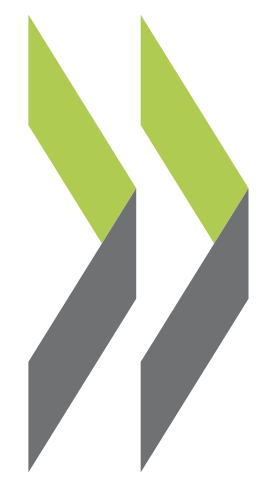

OECD Economics Department Working Papers No. 1571

Naomitsu Yashiro,

Policies for stronger productivity growth in Latvia

Caroline Klein, Olga Rastrigina, Ania Thiemann 


\section{ECONOMICS DEPARTMENT}

\section{POLICIES FOR STRONGER PRODUCTIVITY GROWTH IN LATVIA}

\section{ECONOMICS DEPARTMENT WORKING PAPERS No. 1571}

By Naomitsu Yashiro, Caroline Klein, Olga Rastrigina and Ania Thiemann

OECD Working Papers should not be reported as representing the official views of the OECD or of its member countries. The opinions expressed and arguments employed are those of the author(s).

Authorised for publication by Isabell Koske, Deputy Director, Country Studies Branch, Economics Department.

All Economics Department Working Papers are available at www.oecd.org/economy/workingpapers.

JT03452327 
OECD Working Papers should not be reported as representing the official views of the OECD or of its member countries. The opinions expressed and arguments employed are those of the author(s).

Working Papers describe preliminary results or research in progress by the author(s) and are published to stimulate discussion on a broad range of issues on which the OECD works.

Comments on Working Papers are welcomed, and may be sent to OECD Economics Department, 2 rue André Pascal, 75775 Paris Cedex 16, France, or by e-mail to eco.contact@oecd.org.

All Economics Department Working Papers are available at www.oecd.org/eco/workingpapers.

This document and any map included herein are without prejudice to the status of or sovereignty over any territory, to the delimitation of international frontiers and boundaries and to the name of any territory, city or area.

The statistical data for Israel are supplied by and under the responsibility of the relevant Israeli authorities. The use of such data by the OECD is without prejudice to the status of the Golan Heights, East Jerusalem and Israeli settlements in the West Bank under the terms of international law.

On 25 May 2018, the OECD Council invited Colombia to become a Member. At the time of publication the deposit of Colombia's instrument of accession to the OECD Convention was pending and therefore Colombia does not appear in the list of OECD Members and is not included in the OECD zone aggregates.

\section{(C) OECD (2019)}

You can copy, download or print OECD content for your own use, and you can include excerpts from OECD publications, databases and multimedia products in your own documents, presentations, blogs, websites and teaching materials, provided that suitable acknowledgment of OECD as source and copyright owner is given. All requests for commercial use and translation rights should be submitted to rights@oecd.org 


\section{ABSTRACT/RÉSUMÉ}

\section{Policies for stronger productivity growth in Latvia}

Latvia's productivity growth is held back by weak innovation and inefficient resource allocation. The shortage of skilled workers which constrains innovation and the adoption of digital technologies must be addressed through further alignment of vocational and tertiary education with labour market demand. Strengthening the innovation ecosystem by improving the quality of research and collaboration between firms and research institutions would help to diffuse digital technologies more widely across the economy. Fighting widespread informality, improving the low debt recovery through a more efficient insolvency regime, and reducing substantial state ownership would improve the allocation of resources. Latvia also relies heavily on EU funds to finance its important structural policies. The continuity of the most effective EU funded policy instruments needs to be ensured in the medium term, by integrating them into the national budget.

This Working Paper relates to the 2019 OECD Economic Survey of Latvia

(http://www.oecd.org/economy/surveys/latvia-economic-snapshot/)

JEL classification: G28, I28, J08, L30, O17, O20, O38, O43, O52

Keywords: Latvia, Productivity, Access to credit, Skills shortage, Innovation, Competition, Informality, EU Structural funds

\section{Des politiques en faveur d'une plus forte croissance de la productivité en Lettonie}

La faiblesse de l'innovation et les inefficiences dans l'allocation des ressources brident la croissance de la productivité en Lettonie. Il faudrait remédier au déficit de main-d'œuvre qualifiée, qui pèse sur l'innovation et l'adoption des technologies du numérique, en adaptant mieux l'enseignement professionnel et supérieur aux besoins du marché du travail. Un renforcement de l'écosystème de l'innovation, qui passerait par une meilleure qualité de la recherche et par des collaborations entre les entreprises et les instituts de recherche, aiderait à une plus large diffusion des technologies numériques dans l'économie. L'allocation des ressources pourrait gagner en efficience en luttant contre le phénomène généralisé de l'économie informelle, en rehaussant le taux de recouvrement des créances grâce à un régime plus efficace de l'insolvabilité et en réduisant la présence massive de l'État au capital des entreprises. Il convient également de souligner que la Lettonie est fortement tributaire des fonds de l'UE pour financer ses grandes politiques structurelles. Parmi les instruments d'intervention financés par l'UE, il faudra assurer la continuité à moyen terme de ceux qui sont les plus efficaces en les intégrant dans le budget national.

Ce document de travail s'appuie sur l'Étude économique 2019 de l'OCDE sur la Lettonie http://www.oecd.org/fr/economie/lettonie-en-un-coup-d-oeil/. Classification JEL : G28, I28, J08, L30, O17, O20, O38, O43, O52

Mots-clés : Lettonie, productivité, accès au crédit, déficit de qualifications, innovation, concurrence, économie informelle, Fonds structurels de l'UE. 


\section{Table of Contents}

Policies for stronger productivity growth ............................................................................................. 6

Productivity growth is held back by low innovation and inefficient resource allocation ................... 6

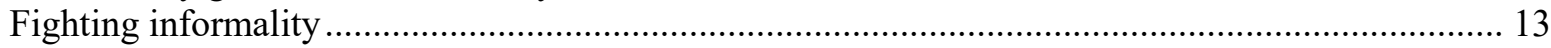

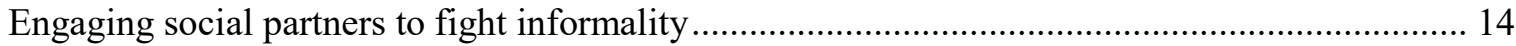

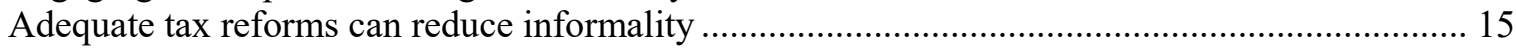

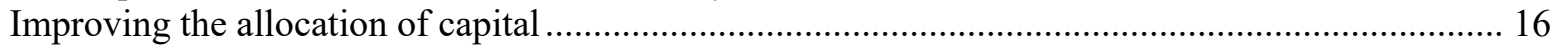

Access to finance remains tight for small young firms ................................................................ 16

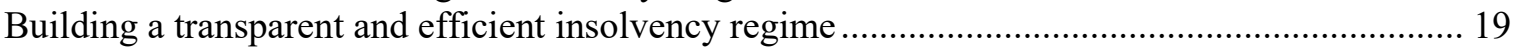

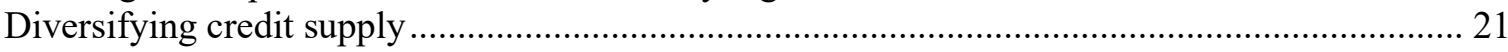

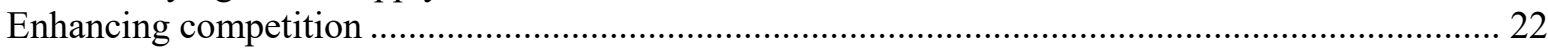

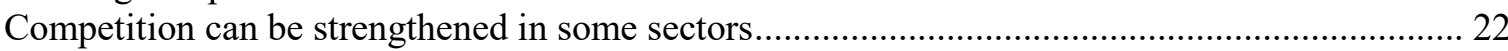

Ensuring fair competition between state-owned and private enterprises ..................................... 24

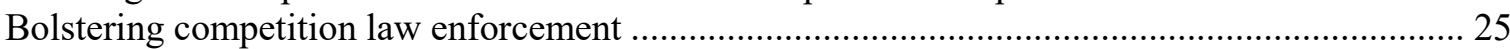

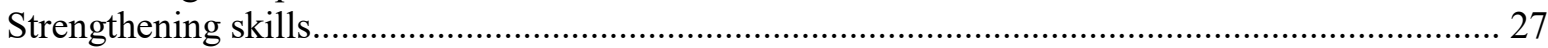

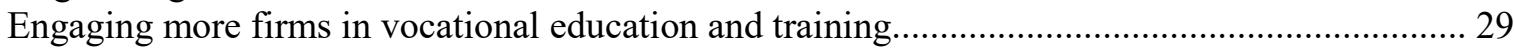

Making tertiary education more responsive to labour market needs .............................................. 31

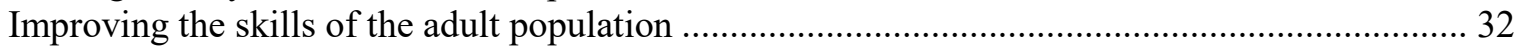

Active labour market policies should receive more stable funding ……........................................ 34

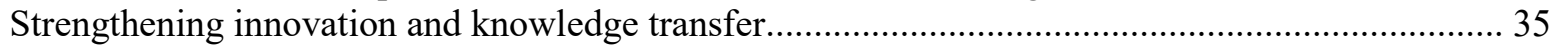

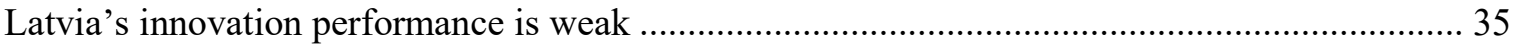

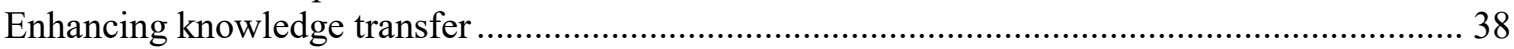

Using EU funds more effectively to promote productivity .............................................................. 40

Ensuring the continuity of the most effective EU-funded policy measures .................................... 40

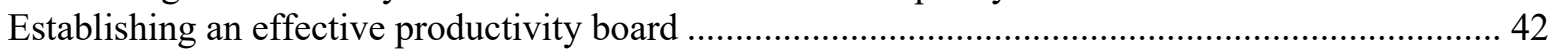

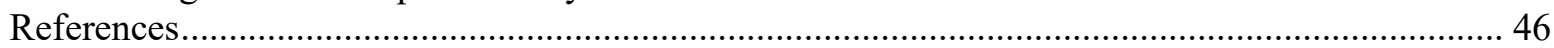

\section{Tables}

Table 1. Resources allocated to the competition authority are low

\section{Figures}

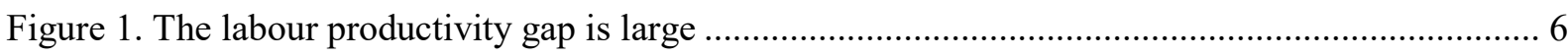

Figure 2. The contribution of capital deepening to labour productivity growth has diminished............. 7

Figure 3. Firm-level productivity and efficiency of resource allocation are low .................................. 8

Figure 4. Better resource allocation has contributed to productivity growth ....................................... 9

Figure 5. Very unprofitable firms are operating especially in some service sectors ............................. 10

Figure 6 . Only the most productive manufacturing firms enjoyed high productivity growth............... 11

Figure 7. Latvian firms lag behind in the use of digital technologies .............................................. 11

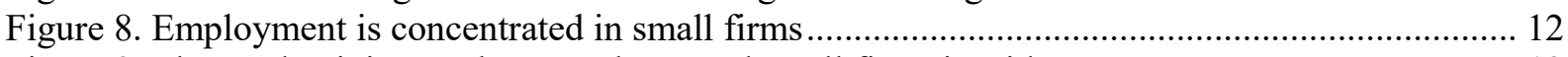

Figure 9. The productivity gap between large and small firms is wide............................................ 12

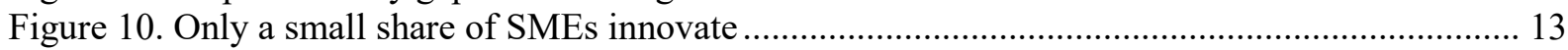

Figure 11. Informality is particularly high in the non-manufacturing sectors.................................... 14

Figure 12. The number of firms using the microenterprise tax regime remains large ......................... 15

Figure 13. Access to finance remains an obstacle to investment ..................................................... 17 
Figure 14. A significant share of firms are reluctant to apply for bank loans ..................................... 17

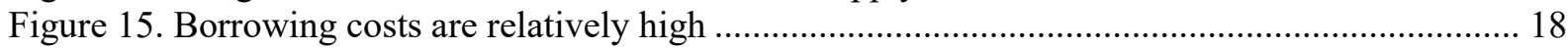

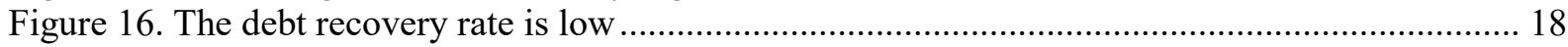

Figure 17. The insolvency regime could be more efficient ................................................................. 19

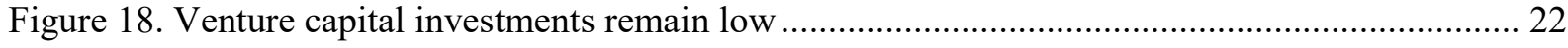

Figure 19. Regulatory settings are competition friendly overall ..................................................... 23

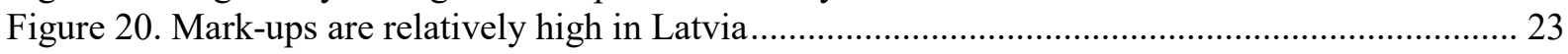

Figure 21. Mark-ups are higher in sectors with many SOEs ............................................................. 24

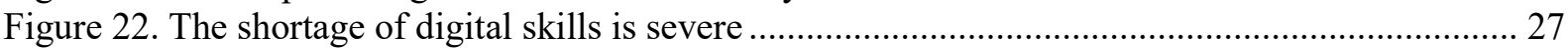

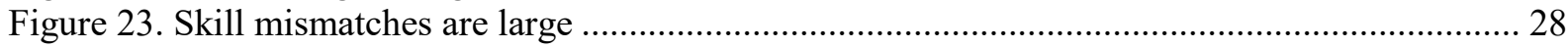

Figure 24. Relatively few firms are managed by professional managers........................................... 33

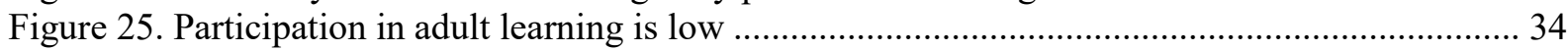

Figure 26. Participation in active labour market policies is low .................................................... 35

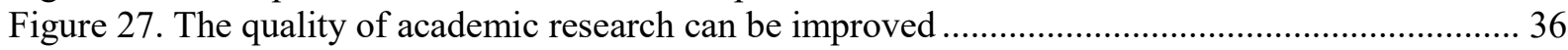

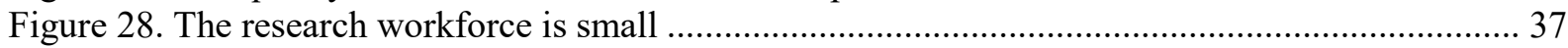

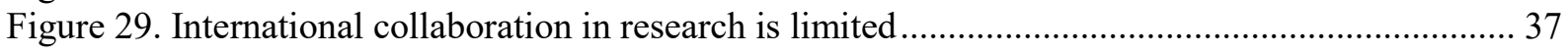

Figure 30. There is little collaboration between SMEs and research institutions................................... 38

Figure 31. Latvia is one of the largest recipients of EU funds ............................................................ 41

\section{Boxes}

Box 1. The role of resource allocation in Latvia's productivity growth ................................................ 8

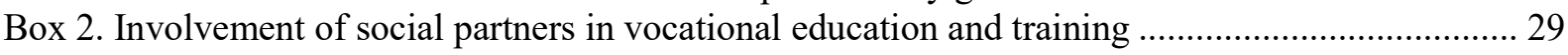

Box 3. Trends in knowledge transfer policies across OECD countries................................................ 39

Box 4. The effect of EU funds on the performance of Latvian firms................................................... 42 


\title{
Policies for stronger productivity growth
}

\author{
By Naomitsu Yashiro, Caroline Klein, Olga Rastrigina and Ania Thiemann ${ }^{1}$ \\ Productivity growth is held back by low innovation and inefficient resource \\ allocation
}

Given a rapidly declining working-age population, Latvia needs strong productivity growth for continuous convergence of living standards with other OECD countries. Labour productivity growth in Latvia resumed quickly after a decline in the aftermath of the financial crisis. However, it has slowed down considerably compared to the pre-crisis period when it was fuelled by large capital inflows, rapid debt accumulation and a real estate boom, which was unsustainable (Blanchard et al., 2013). Productivity growth needs to pick up from current levels considering that the gap in labour productivity against highincome OECD countries remains larger than for other Baltic or Central European countries (Figure 1). It has to be driven by stronger innovation, a better use of skills and a more efficient allocation of scarce resources. Improving access to finance, training and support for innovation for Latvia's less productive small and medium enterprises will help them improve their productivity and strengthen inclusive growth.

Figure 1. The labour productivity gap is large

The gap in GDP per hour worked against 17 richest OECD countries, 2017

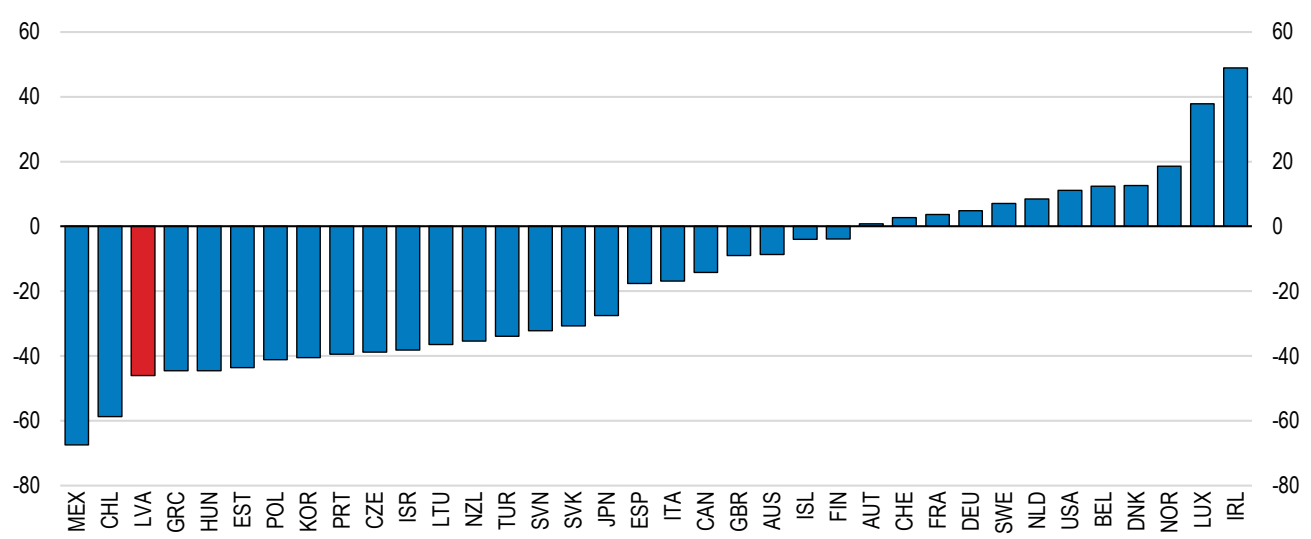

Note: Compared to the weighted average using population weights of the 17 OECD countries with highest GDP per capita in 2017 based on 2017 purchasing power parities (PPPs). Labour productivity is measured as GDP per hour worked.

Source: OECD (2019) Going for Growth.

StatLink त्गा5म https://doi.org/10.1787/888933926623

\footnotetext{
${ }^{1}$ Naomitsu Yashiro, Caroline Klein, Olga Rastrigina and Ania Thiemann are respectively Economist (Economics Department), Senior Economist (Economics Department), Junior Economist (Directorate for Employment, Labour and Social Affairs) and Economist (Directorate for Financial and Enterprise Affairs) at the OECD. This paper benefitted from the joint research with Konstantins Benkovskis (Stockholm School of Economics at Riga/Bank of Latvia), Olegs Tkacevs (Bank of Latvia) and Anna Zasova (Stockholm School of Economics at Riga) and valuable comments and suggestions from Isabell Koske, Nicola Brandt, Christine Lewis, Christina Timiliotis (OECD/ECO), Dirk Pilat, Caroline Paunov, Alexander Himbert (OECD/STI), Paolo Falco, Katherine Mullock (OECD/ELS) and Samuel Kim (OECD/EDU). Corinne Chanteloup and Elisabetta Pilati provided statistical and editorial support. All remaining errors are due to the authors.
} 
The marked slowdown of labour productivity growth after 2008 resulted partly from a deceleration in capital deepening, as investment was subdued (Figure 2). Sluggish business investment was the consequence of the restructuring of large debt in the aftermath of the global financial crisis. Access to finance tightened significantly, as bank lending to nonfinancial enterprises kept decreasing until recently and remains negligible. A slow and inefficient insolvency regime with low recovery rates and a large share of undeclared earnings have contributed to the sluggish recovery of lending. This prevented productive firms from financing investment, contributing to misallocation of capital (Benkovskis, 2015).

Figure 2. The contribution of capital deepening to labour productivity growth has diminished

Decomposition of average annual growth in labour productivity, \%

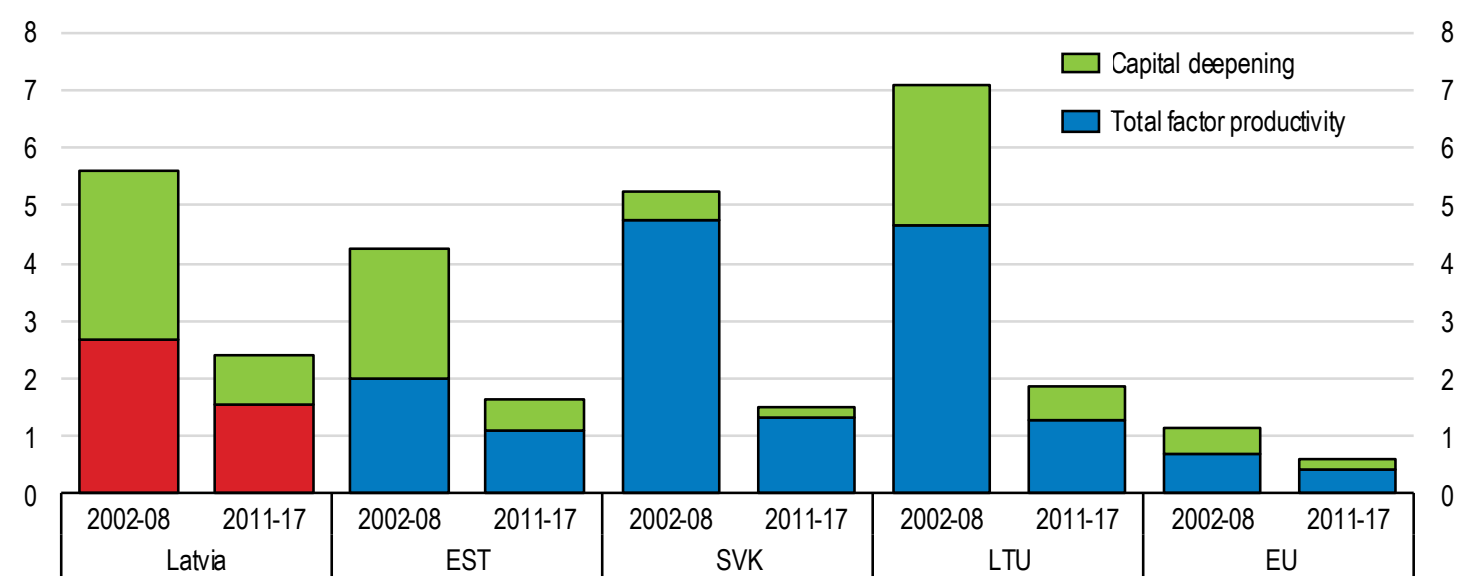

Source: OECD (2019) Going for Growth 2019 Edition.

StatLink त्गा5 https://doi.org/10.1787/888933926642

Latvia's labour productivity in the manufacturing sector is constrained by the low levels of productivity within Latvian firms and modest allocative efficiency, that is, the extent to which firms with higher productivity levels have larger shares in employment (Box 1, Figure 3). The reallocation of labour toward more productive firms has progressed to some extent after the crisis (Box 1, Figure 4). This was partly due to tighter competition in the domestic market that forced unproductive firms to scale down their production or exit the market (Benkovskis, 2015). However, very unprofitable firms continue to operate, particularly in knowledge-intensive services.

This may be partly the result of vigorous entrepreneurship in Latvia, as young and small firms are often unproductive when they start to operate. Some of them experience fast productivity growth as they catch up to the frontier, while some others remain unprofitable (Berlingieri et al., 2019). It is important to ensure the smooth exit of nonviable firms, so that resources can be reallocated to more productive and innovative firms (AdaletMcGowan et al., 2017). Also, informal economic activities such as under-decleration of corporate profits, employment or wage payments, are widespread (Sauka and Putniņš, 2019; Schneider, 2017). Informal firms are generally less productive than formal firms and they distort resource allocation and competition, making it harder for formal productive firms. 


\section{Box 1. The role of resource allocation in Latvia's productivity growth}

Joint research of the OECD and the Bank of Latvia (Benkovskis et al., 2019) analyses the extent to which the efficiency of resource allocation contributes to productivity growth in Latvia.

\section{The contribution of resource allocation to labour productivity level}

Sector-level productivity $P_{t}$ at time $t$, can be decomposed into the simple mean of firmlevel productivity and the covariance between productivity and firms size as below, following Olley and Pakes (1996):

$$
P_{t}=\frac{1}{N_{t}} \sum_{i} P_{i, t}+\sum_{i}\left(\theta_{i, t}-\bar{\theta}_{t}\right)\left(P_{i, t}-\bar{P}_{t}\right)
$$

$P_{i, t}$ is the productivity level of a firm $i$ at time $t, N$ represents the number of firms in a sector, $\theta_{i, t}$ is the employment share of firm $i$ at time $t, \bar{P}_{t}$ and $\overline{\boldsymbol{\theta}}_{t}$ are sector-level averages. The second term, referred to as allocative efficiency, captures to what extent more productive firms are larger than others in terms of employment, or in other words the extent to which resources are efficiently allocated to the most productive firms, helping them grow.

Latvia's labour productivity in the manufacturing sector is low compared to high-income OECD countries partly due to low productivity of Latvian firms. But the contribution to productivity from more efficient resource allocation is also low (Figure 3). The larger size of more productive firms (allocative efficiency) contributes about $35 \%$ to aggregate productivity, lower than some countries like Hungary where this share is $67 \%$.

Figure 3. Firm-level productivity and efficiency of resource allocation are low

Decomposition of labour productivity into mean productivity and allocative efficiency, manufacturing sector

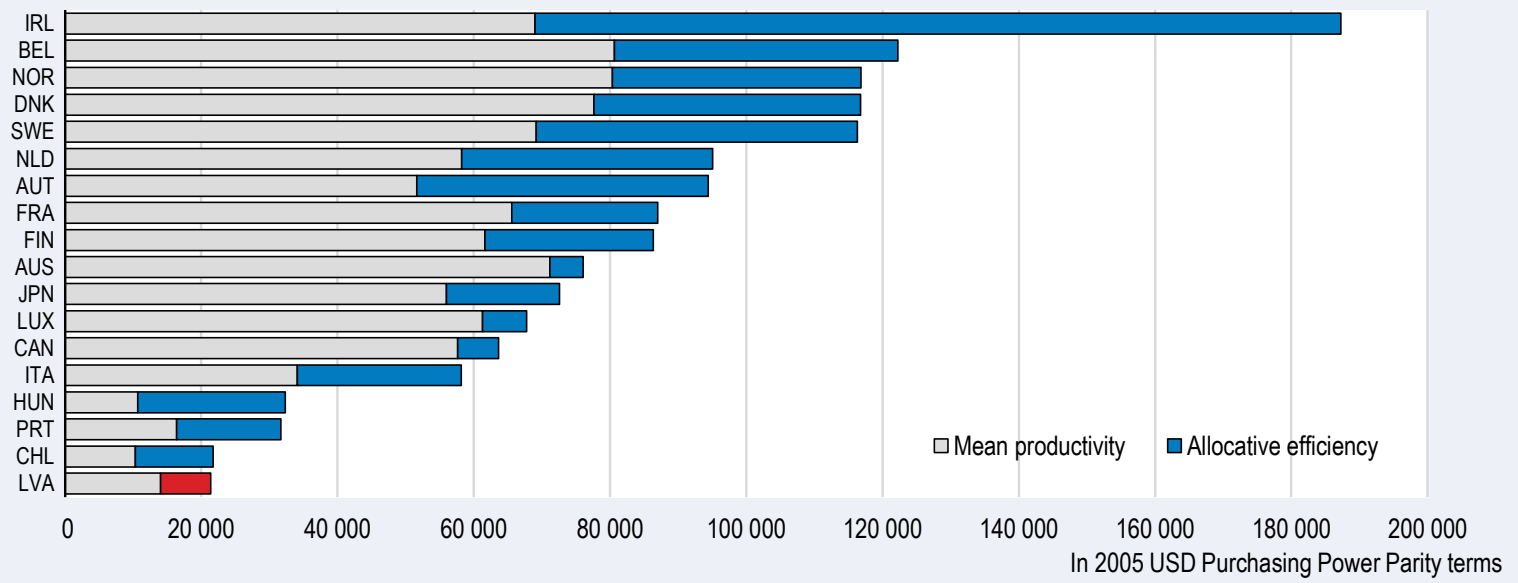

Note: Data refer to 2011 due to limited availability of data for other countries in more recent years.

Source: Latvia data are from Benkovskis, K., O. Tkacevs and N. Yashiro (2019), "The role of resource allocation in Latvia's productivity", OECD Economics Department Working Papers, OECD Publishing, Paris, forthcoming.. The Ireland data are from: Papa, J., Rehill, L., and O’Connor, B., "Patterns of Firm Level Productivity in Ireland", OECD Productivity Working Papers, 2018-15, OECD Publishing, Paris. Other countries' data are from Berlingieri, G., et al. (2017), "The Multiprod project: A comprehensive overview", OECD Science, Technology and Industry Working Papers, No. 2017/04, OECD Publishing, Paris. 


\section{The contribution of resource allocation to labour productivity growth}

Sector-level productivity growth $\Delta p_{t}$ can also be decomposed into the contribution of improving resource allocation and the mean productivity growth of Latvian firms as well as the entry of new firms and the exit of unproductive firms, following the dynamic version of the Olley-Pakes decomposition developed by Melitz and Polanec (2015):

$$
\Delta p_{t}=\frac{1}{N^{C}} \sum_{i \in C}\left(p_{i t}-p_{i t-1}\right)+\Delta \underset{i \in C}{\operatorname{cov}}\left(\theta_{i t}, p_{i t}\right)+\left(\sum_{i \in E} \theta_{i t}\right) \cdot\left(p_{t}^{E}-p_{t}^{C}\right)+\left(\sum_{i \in X} \theta_{i t-1}\right) \cdot\left(p_{t-1}^{C}-p_{t-1}^{X}\right)(2)
$$

The first term is the unweighted change of the productivity of incumbents; the second term is the change in allocative efficiency among incumbent firms through stronger growth of more productive firms; and $p_{t}^{E}, p_{t}^{C}, p_{t-1}^{X}$ are the weighted productivity averages of respectively entering, incumbent and exiting firms computed in the relevant time period. $\theta_{i, t}$ is the employment share that sums up to one when aggregated across firms within each group.

The improvement in allocative efficiency contributed positively to labour productivity growth in both manufacturing and service sectors, along with the exit of unproductive firms (Figure 4).

Figure 4. Better resource allocation has contributed to productivity growth

The decomposition of labour productivity growth, $\%$ and percentage points

Change in mean productivity of incumbents

Exit

A. Manufacturing sector

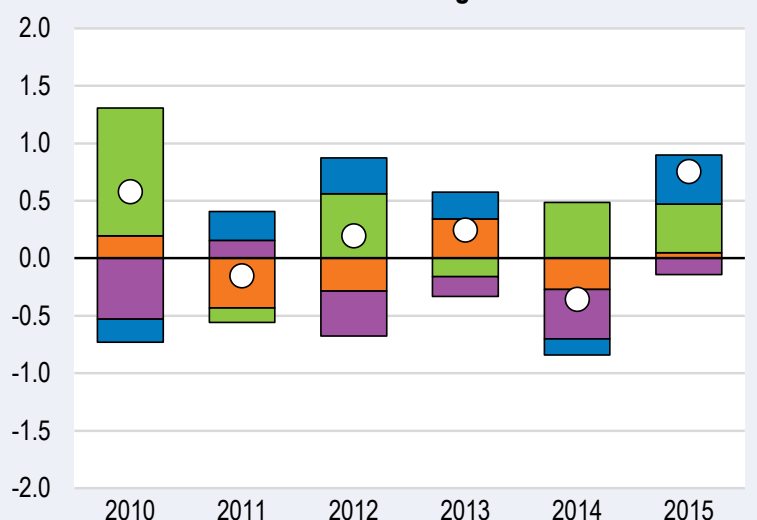

Change in allocative efficiency Productivity growth

\section{B. Services sector}

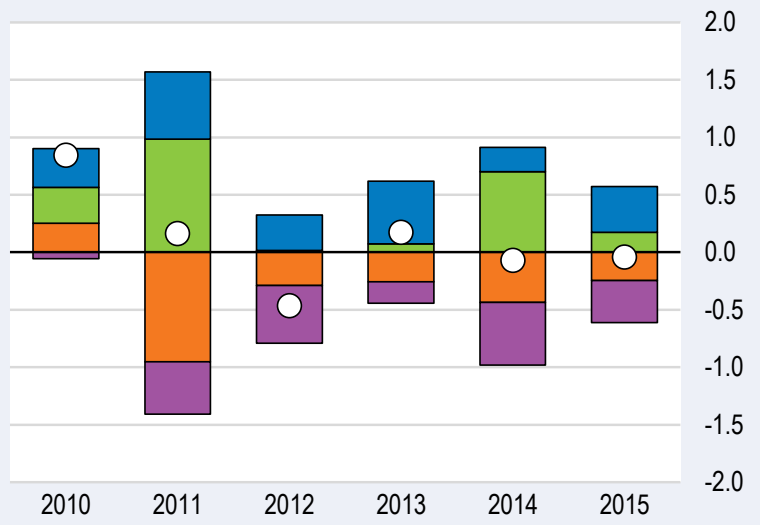

Note: Allocative efficiency refers to the extent to which firms with higher productivity have larger shares in employment.

Source: Benkovskis, K., O. Tkacevs and N. Yashiro (2019), "The role of resource allocation for Latvia's productivity”, OECD Economics Department Working Papers, OECD Publishing, Paris, forthcoming. 


\section{Figure 5. Very unprofitable firms are operating especially in some service sectors}

The mark-up of least profitable firms compared to the median mark-up, average over 2011-2015

\begin{abstract}
Transportation and storage
Manufacturing

Energy and other utility services

Accommodation and food service activities

Construction

Wholesale and retail trade

Information and communication

Professional, scientific and technical activities

Administrative and support service activities
\end{abstract}

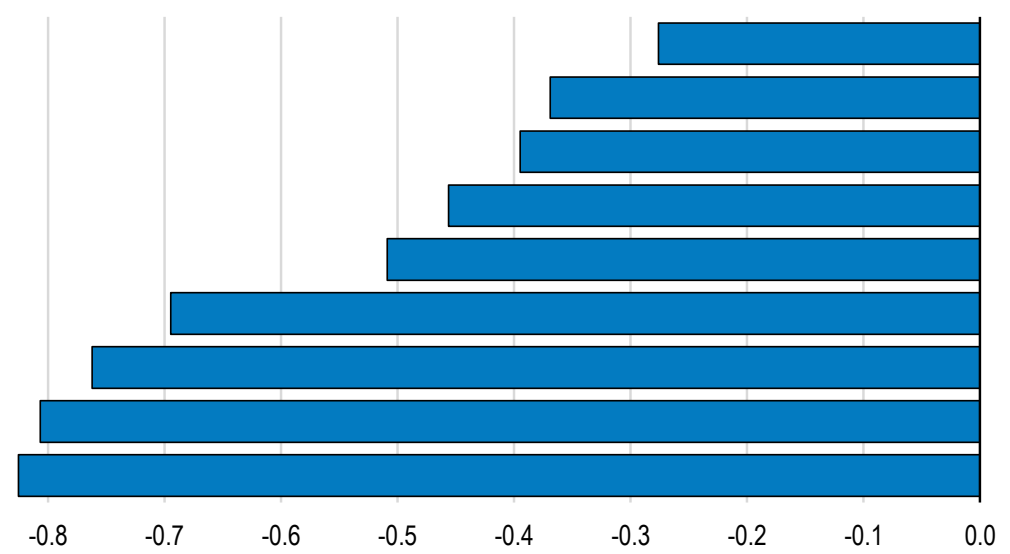

$-0.8-0.7$

$-0.6$

$-0.5$

$-0.1$

0.0

Note: The chart displays for each sector the gap between the mark-ups of the least profitable firms (defined as firms corresponding to the bottom decile of the mark-ups distribution) and the median mark-ups. A larger gap indicates a larger variance in mark-ups in the lower half of the distribution (firms with profits that are below the median). Mark-ups are computed from the microdata of Latvian firms, as the ratio of value added excluding labour costs and turnover. Mark-ups are averaged over the period 2011-15.

Source: Benkovskis, K., O. Tkacevs and N. Yashiro (2019), “The role of resource allocation in Latvia's productivity”, OECD Economics Department Working Papers, OECD Publishing, Paris, forthcoming..

StatLink त्गा5म https://doi.org/10.1787/888933926699

Productivity growth of incumbent firms has been subdued or negative, especially in the service sector (Box 1, Figure 4). Only the most productive manufacturing firms experienced robust productivity growth after the crisis, while productivity growth was subdued among other less productive firms (Figure 6, Panel A). Such divergence in productivity across firms suggests that only the most technologically advanced firms have capitalised on new technologies while their diffusion throughout the economy has been limited, as observed across several OECD countries (Andrews et al., 2016). In services, productivity growth was weak even for the most productive firms (Figure 6, Panel B), unlike in other OECD countries where those firms realised considerably faster productivity growth (Andrews et al., 2016). The weak performance of the frontier firms in the service sector might be due to limited competition and a large role of state-owned enterprises in some service sectors.

Only a few Latvian firms adopt new technologies or introduce organisational improvements and more efficient production techniques. In particular, Latvia lags considerably behind other OECD countries in the use of digital technologies (Figure 7). Although the take-up of high speed broadband is above the EU average (European Commission, 2018a), poor ICT skills and skills that complement ICT, such as advanced management, limit the capacity of Latvian firms to make the best use of the latest digital technologies such as big data analysis. For instance, a half of the population lack basic digital skills (European Commission, 2018a).

The share of small firms is particularly large in Latvia (Figure 8). Their productivity is considerably lower than that of large firms, and such gap in productivity is larger than in many other OECD countries (Figure 9). This reflects the lower capacity of small firms to adopt new technologies and improve the efficiency of production procedures. Indeed, the share of innovating SMEs is among the lowest in the OECD (Figure 10). Policies to 
improve skills and access to finance and to stimulate innovation therefore always have to adapt to the specific needs of small enterprises.

Figure 6. Only the most productive manufacturing firms enjoyed high productivity growth

The labour productivity of the most productive firms versus others, indexed as $2009=100$

$$
\text { Median }
$$

\section{A. Manufacturing sector}

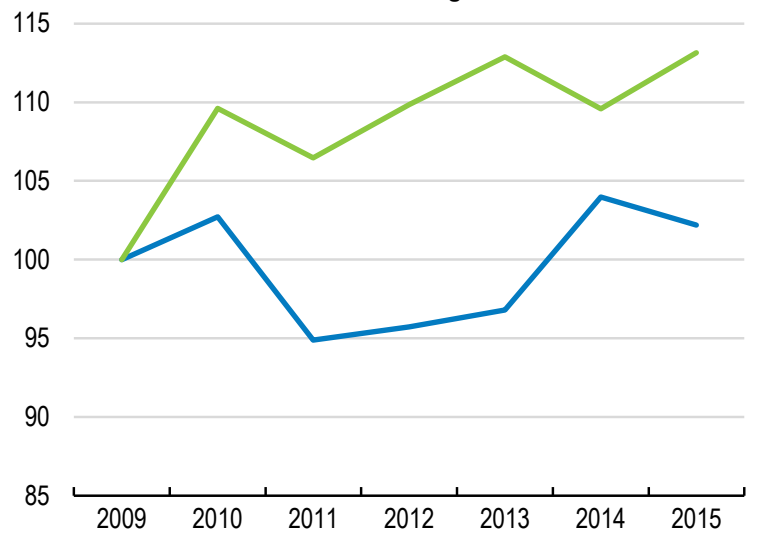

Most productive firms

\section{B. Services sector}

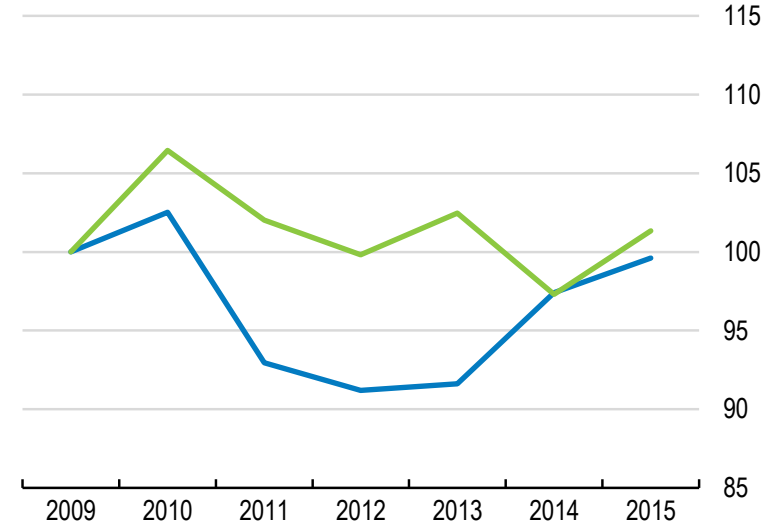

Note: The most productive firms are those at the top decile of the productivity distribution of the corresponding sector. The other firms are represented by the median of the productivity distribution. Only the firms that were active during 2007-2015 are analysed. The top decile and median firms can differ from year to year. Source: Benkovskis, K., O. Tkacevs and N. Yashiro (2019), "The role of resource allocation in Latvia's productivity", OECD Economics Department Working Papers, OECD Publishing, Paris, forthcoming..

\section{StatLink त्राजा https://doi.org/10.1787/888933926718}

\section{Figure 7. Latvian firms lag behind in the use of digital technologies}

Enterprises using specific digital technologies, percentage of enterprises, 2017 or latest available year

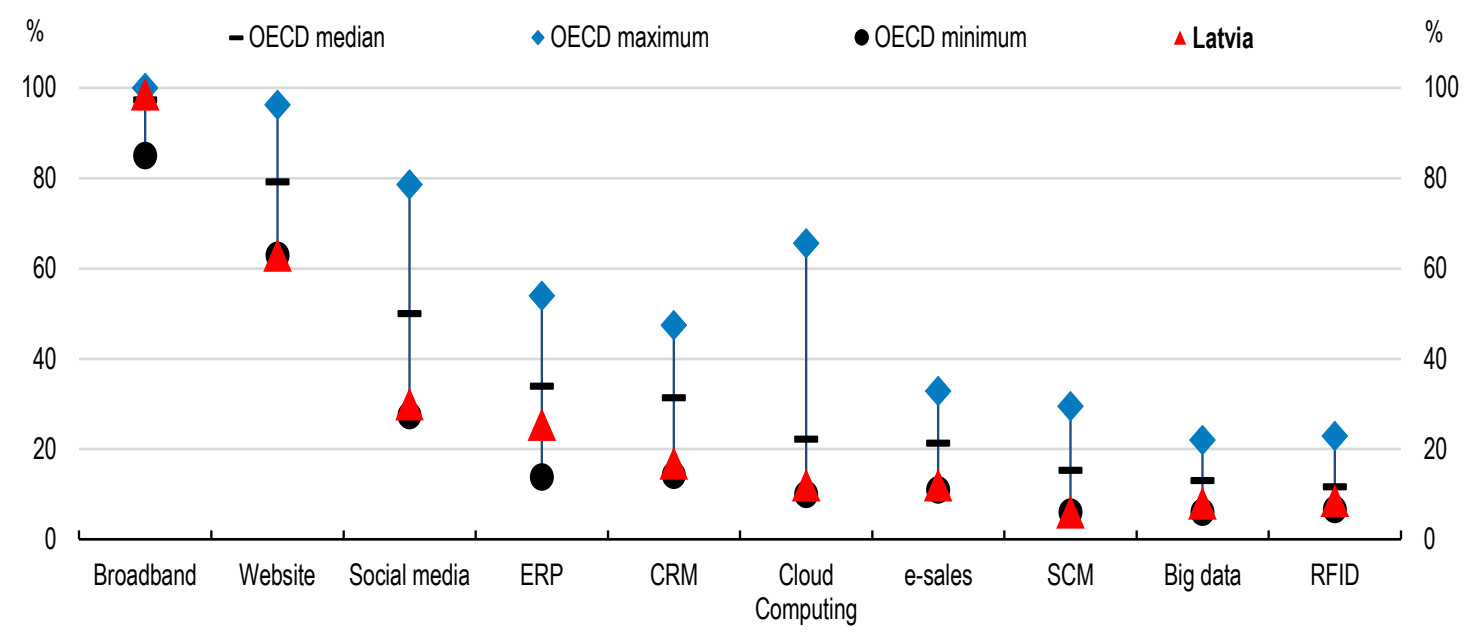

Note: Data cover 26 OECD countries and correspond to the share of businesses with ten or more employees with broadband connection (fixed or mobile); with a website or home page; using social media; using Enterprise Resource Planning (ERP) software; using Customer Relationships Management (CRM) software; purchasing cloud computing services; receiving orders over computer networks; sharing electronically information with suppliers and customers (SCM); using Radio Frequency Identification (RFID) technology; and having performed big data analysis (2018 data).

Source: OECD ICT Access and Usage by Businesses Database and Eurostat.

StatLink त्ञाs https://doi.org/10.1787/888933926737 
Figure 8. Employment is concentrated in small firms

Employment by enterprise size, business economy, 2016 or latest available year

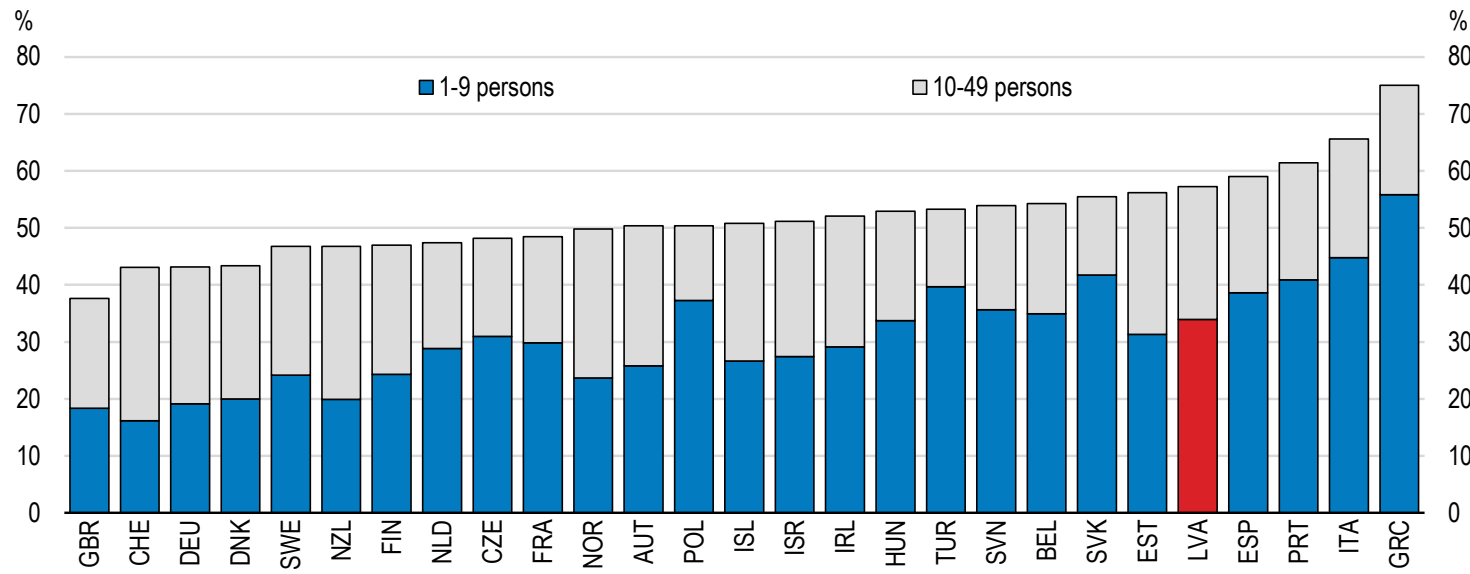

Note: Percentage of all persons employed.

Source: OECD Structural and Demographic Business Statistics (SDBS) database.

StatLink त्गा5 https://doi.org/10.1787/888933926756

Figure 9. The productivity gap between large and small firms is wide
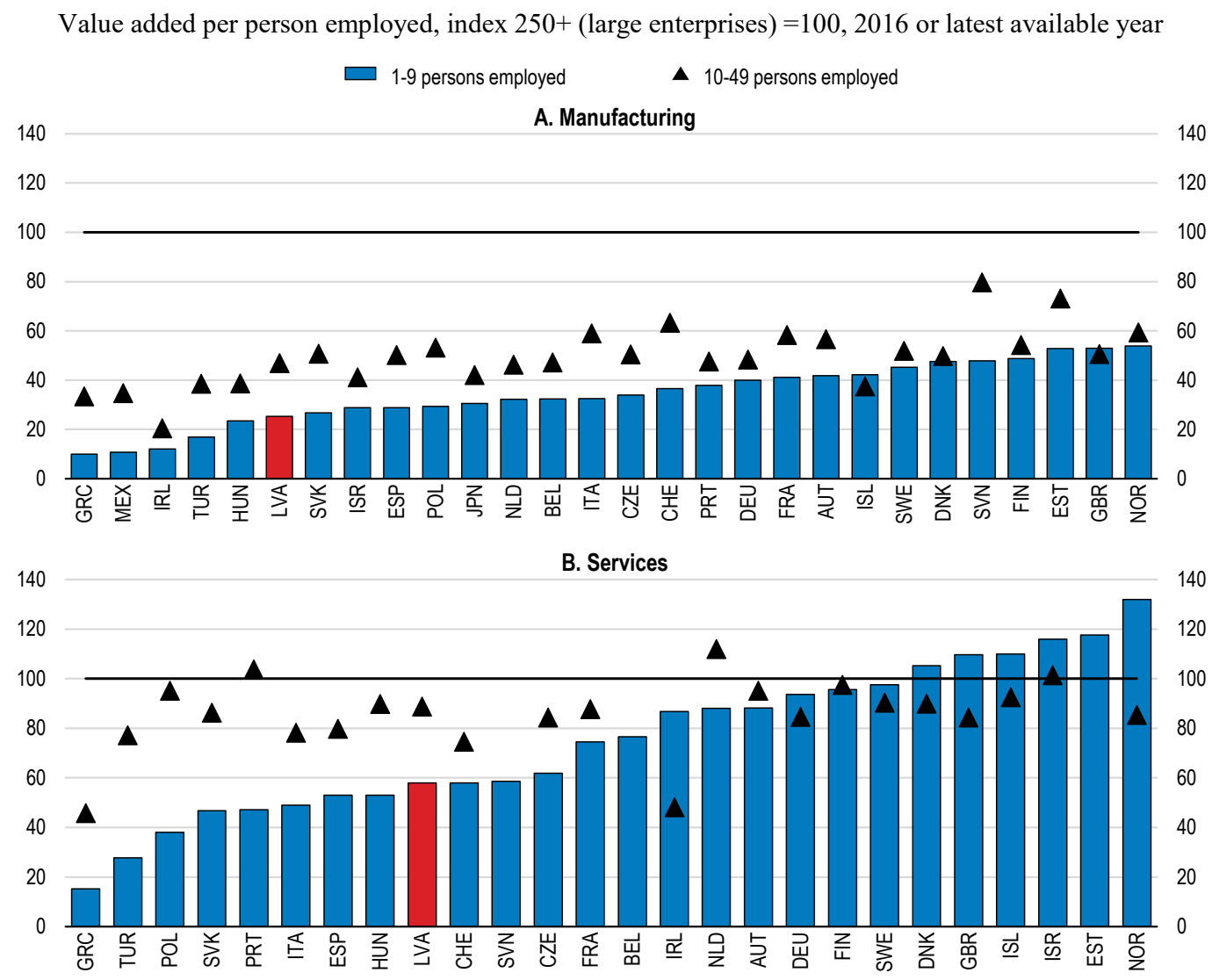

Source: OECD Structural and Demographic Business Statistics database.

StatLink त्गाडs https://doi.org/10.1787/888933926775 
Figure 10. Only a small share of SMEs innovate

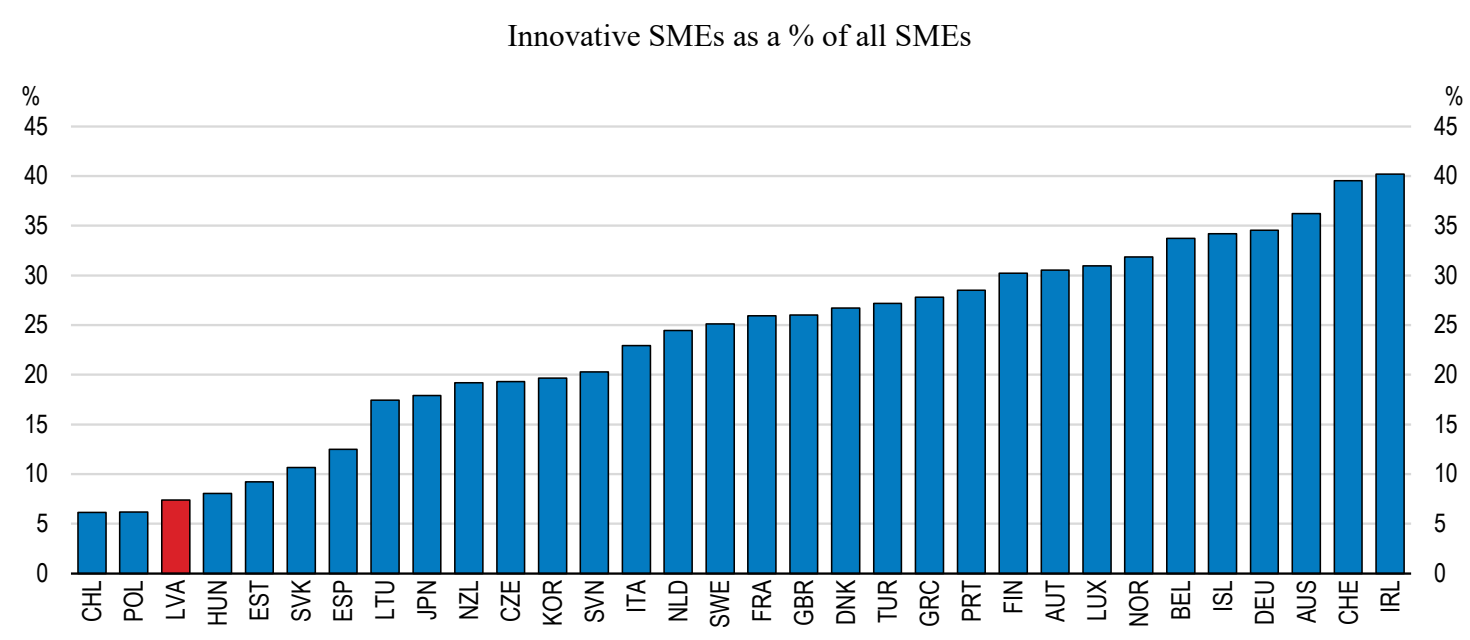

Note: Innovating SMEs are those introducing product, process, marketing or organisational innovation. Source: OECD (2017), OECD Science, Technology and Industry Scoreboard 2017: The digital transformation, OECD Publishing, Paris.

\section{StatLink त्माज् https://doi.org/10.1787/888933926794}

The next section discusses how reducing the high level of informality can contribute to productivity growth. It is followed by a section on polices to strengthen capital allocation through improved bank lending and SME's access to finance. The chapter then discusses policies to ensure fair competition in markets dominated by state-owned enterprises. This is be followed by a review of policies to strengthen workers' skills and better align them with labour market needs, and policies to improve the quality of research, innovation and knowledge transfer from research institutions to firms. The chapter then highlights the need to ensure the continuity of a wide range of essential policy measures financed by EU funds and enhance their effectiveness in boosting productivity growth. The final section discusses the importance of establishing an effective institution that is tasked to promote productivity growth.

\section{Fighting informality}

The shadow economy, which comprises under-declared corporate income, income of unregistered firms, and income from illegal activities has decreased since the financial crisis, but is considered to have amounted to 24\% of Latvia's GDP in 2018 (Sauka and Putniņš, 2019). Informal economic activities such as under-declaration of business income, employment or wage payment, are especially high in the construction sector, while they are relatively low in the manufacturing sector (Figure 11). 
Figure 11. Informality is particularly high in the non-manufacturing sectors

Perceived share of informality by sector, \%, 2017

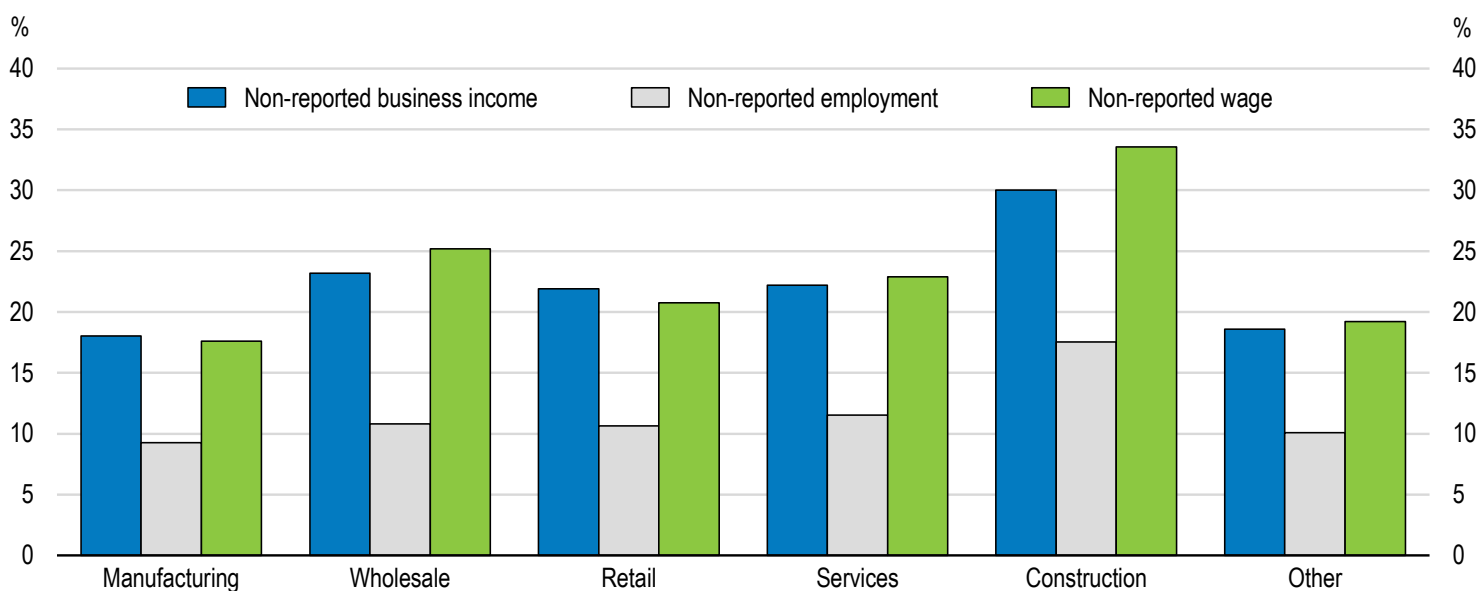

Note: The chart summarises the perceived share of informal economic activities by the surveyed firm managers in the sector they operate.

Source: Survey on Latvian firm managers conducted by the Baltic International Centre for Economic Policy Studies (BICEPS) under the Latvian State Research Programme SUSTINNO.

StatLink त्ञाज https://doi.org/10.1787/888933926813

Widespread informality constrains productivity growth. For instance, firms underdeclaring their revenues cannot prove their profitability and creditworthiness, making it difficult to access credit to finance their investment. There are also negative spillovers, as formal firms operating in sectors where a perception of informality is high can face tighter lending conditions (Distinguin et al., 2016). The inability to finance their investment prevents firms from improving competitiveness and may lock them in the informal sector. Unfair competition with firms under-declaring corporate profits and employment and thus saving on tax and social security contributions erodes the market shares and profits of formal firms. This would reduce the ability of formal firms to finance investment and grow.

\section{Engaging social partners to fight informality}

The government has been engaging in extensive efforts to reduce informality. Coordination between relevant ministries was improved to make the fight against informality more effective. Ministers meet regularly to discuss progress and define the way forward. A recent agreement with the construction sector increased the sectoral minimum wage, while introducing real-time electronic record keeping of workers on construction sites, making under-reporting of wages and working hours more difficult. Declared working hours have increased substantially as a result and similar agreements with other sectors are planned. The government has also developed guidelines for public procurement procedures to help buyers assess bidders' compliance risks, including with tax and labour laws.

Improving trust in the government and the rule of law is essential for strengthening tax morale and incentives for compliance by firms and workers (OECD, 2017a). The government has foreseen larger budgets and new posts for several law enforcement agencies, including the Financial Regulator, the Financial Intelligence Unit and the Corruption Prevention and Combating Bureau (KNAB). However, actual hiring procedures have been slow and staff have not increased as planned in any of these institutions. 
Providing for transparency and consultation in law-making and ensuring that law enforcement agencies build good relations with businesses and citizens help them comply with laws. Such efforts are equally important as fines for infractions. The recent "Consult first" initiative is welcome. Under this initiative, large law enforcement agencies, including the tax and insolvency administrations, support business compliance, instead of fining firms immediately for infractions.

\section{Adequate tax reforms can reduce informality}

Some features of the tax system likely encourage under-declaration of profits. Some Latvian firms may hide part of their revenue to remain eligible for the special tax regime for microenterprises. The microenterprise tax regime adopted in 2010 provides strong incentives for firms to stay small or split into smaller units to avoid growing above the eligibility threshold (Jacobs et al., 2017). This effect was most pronounced in sectors with high labour costs, such as professional services. The loss of efficiency due to such threshold-induced distortions can be significant. It is estimated at around 3.5\% of GDP in the case of France (Garciano et al., 2016).

The number of firms under the microenterprises tax regime increased by $350 \%$ between 2011 and 2016 (Figure 12), accounting for $24 \%$ of all economically active firms at its peak in 2016 according to the Central Statistical Bureau. The share of enterprises declaring low profits increased significantly during the same period (Benkovskis et al., 2019). The number of microenterprises decreased after 2016 as the eligibility for the regime was tightened, but remains large (Figure 12). The government should phase out the microenterprise tax regime, considering its potentially negative impact on productivity growth. The regime can be replaced for instance by a tax credit targeted at new firms, which offsets corporate income tax payments or social security contributions for a limited period of time after their birth (Jacobs et al., 2017).

Figure 12. The number of firms using the microenterprise tax regime remains large

The number of firms operating under the microenterprise tax regime

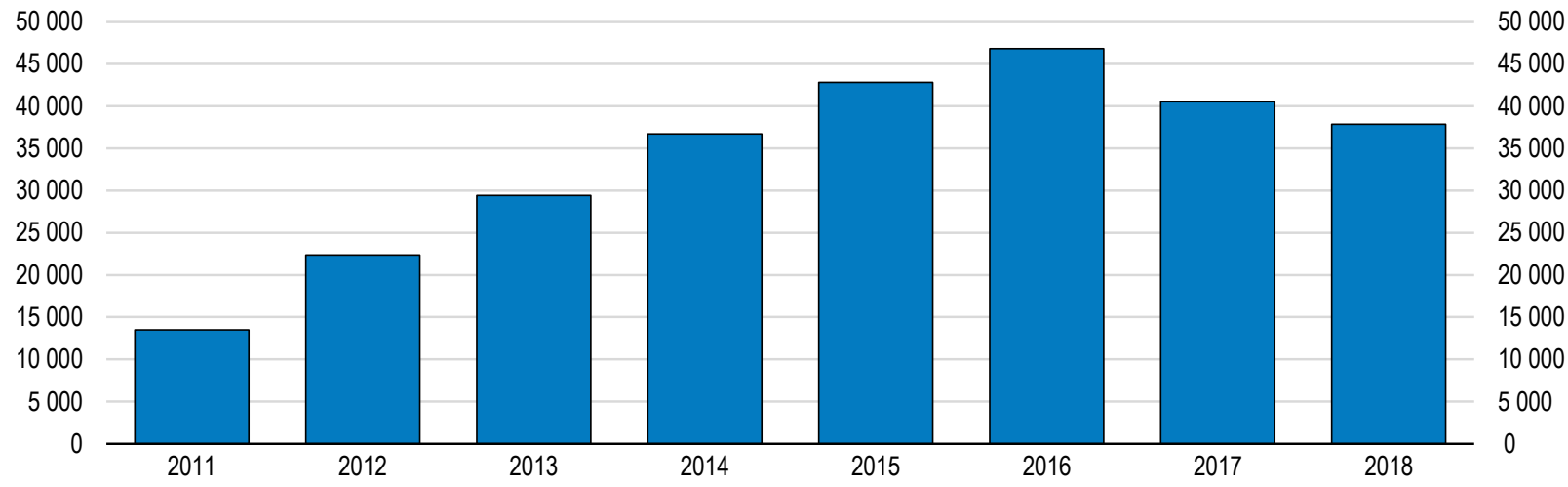

Source: The Bank of Latvia

StatLink : तils https://doi.org/10.1787/888933926832

The corporate tax reform in 2018 that deferred the taxation of corporate income until its distribution was partly intended to entice more companies to fully declare their profits, improving access to credit. However, there are considerable uncertainties about the extent 
to which the tax reform will reduce informality, increase investment and support productivity growth. In particular, the reform may undermine productivity growth by creating distortions to capital allocation (OECD, 2009). For instance, by discouraging the payment of dividends, it may impede capital mobility and lock in capital in old and potentially less productive firms.

One assessment of a similar tax reform in Estonia argued that the reform increased reported corporate profits (Praxis Center for Policy Studies, 2010). On the other hand, Hazak (2009) concluded that Estonian companies reacted mainly by accumulating liquid assets rather than investing. The evidence regarding effects of the tax reform on productivity is also mixed (Staehr, 2014; Masso et al., 2013). The government should carefully evaluate the impact of the reform on formality, investment and firms' performance to assess whether this reform yields the expected benefits.

\section{Improving the allocation of capital}

\section{Access to finance remains tight for small young firms}

Good access to finance at a reasonable cost is a necessary condition for cash-constrained firms to invest in productivity-enhancing capital (OECD, 2015a). In addition, smooth allocation of capital to more productive firms boosts Latvia's overall productivity by allowing those firms to become larger (Midrigan and Xu, 2014; Moll, 2014). In Latvia, low debt recovery rates and strict capital requirements for banks induced a substantial tightening of lending standards in the aftermath of the global financial crisis. Although corporate indebtedness has declined significantly since then, investment remained weak and the allocation of capital improved little (Benkovskis, 2015).

Lending to non-financial corporations in Latvia has remained subdued even though borrowing costs have reached historically low levels, supported by accommodative ECB monetary policy. The weak credit growth can be partly attributed to the weak demand for banking credit from the corporate sector. In fact, since 2009, corporate savings have significantly exceeded business investment on the aggregated level. This suggests that the appetite for investment by Latvian firms remains moderate overall, even if they could finance investment with internal funds.

At the same time, some firms are subject to credit constraints, and the share of such firms is well above the EU average or levels seen in neighbouring countries (Figure 13). Like in most OECD countries, small firms lack sufficient collateral and business history, which makes it harder for them to access credit (OECD, 2019a). According to a survey conducted by the Bank of Latvia, less than half of Latvian SMEs complied with lending standards for the review of their loan application (Bank of Latvia, 2017). Other indicators also point to small firms' apprehension when applying for debt and using banking services. The share of firms that do not apply for bank financing because of possible rejection or do not feel confident talking about financing with banks is among the highest in the EU (Figure 14). 
Figure 13. Access to finance remains an obstacle to investment

Percentage of firms declaring that availability of finance is a major obstacle to long-term investment, 2017

50

40

30

20

10

0

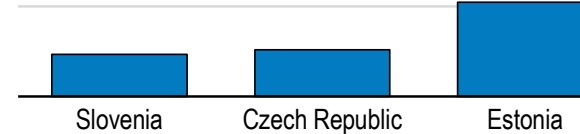

Source: European Investment Bank - EIBIS, EIB Investment Survey

StatLink ज्ञाIs https://doi.org/10.1787/888933926851

Figure 14. A significant share of firms are reluctant to apply for bank loans

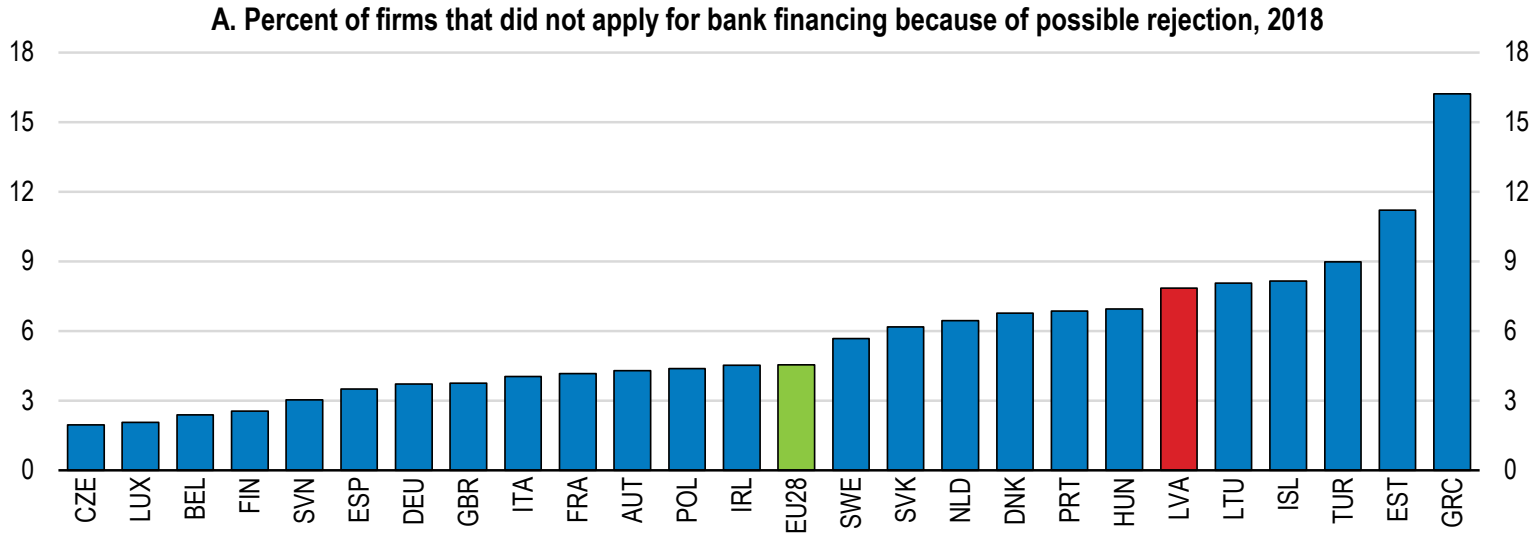

\section{B. Percent of firms that do not feel confident talking about financing with banks, 2018}

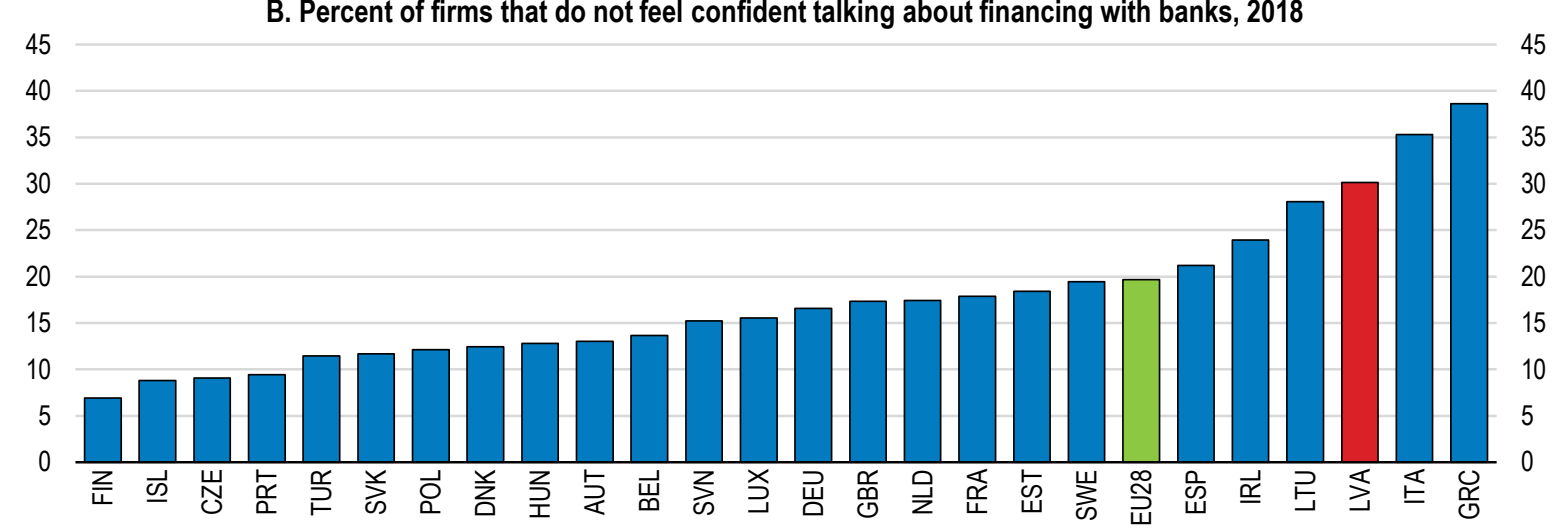

Source: 2018 SAFE Survey on the access to finance of enterprises. 
Tight collateral requirements and conservative lending standards have changed little since the financial crisis (OECD, 2019a). Low debt recovery rates in the aftermath of the crisis owing to an inefficient insolvency regime resulted in large losses by credit institutions and a high perceived lending risk (European Commission, 2018b). This perception still prevails, as indicated by higher borrowing costs in Latvia compared to other euro area countries (Figure 15). The bank lending survey conducted by the ECB also reveals that credit institutions plan to maintain a conservative lending stance (Bank of Latvia, 2018). Raising the debt recovery rate which remains among the lowest in the OECD (Figure 16) is essential for facilitating access to credit by small young firms. At the same time, alternative channels of allocating capital to firms with high growth potential need to be developed.

\section{Figure 15. Borrowing costs are relatively high}

SME interest rates, average 2011-17

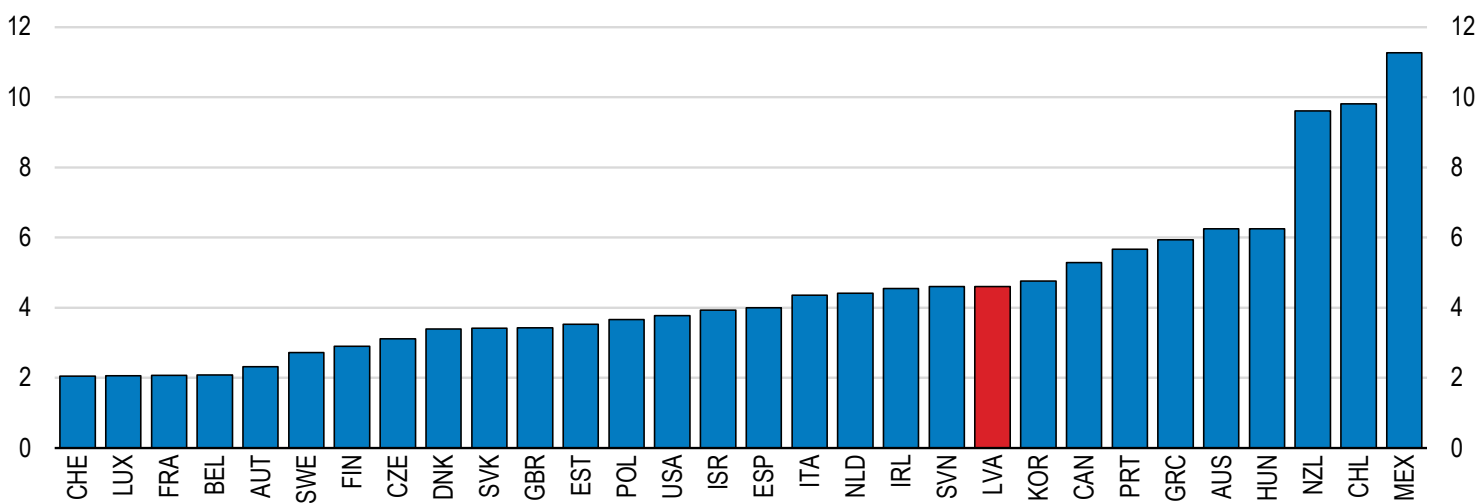

Source: Financing SMEs and Entrepreneurs: An OECD Scoreboard (dataset).

StatLink तiाs https://doi.org/10.1787/888933926889

Figure 16. The debt recovery rate is low

Average recovery rate, cents per a dollar of credit

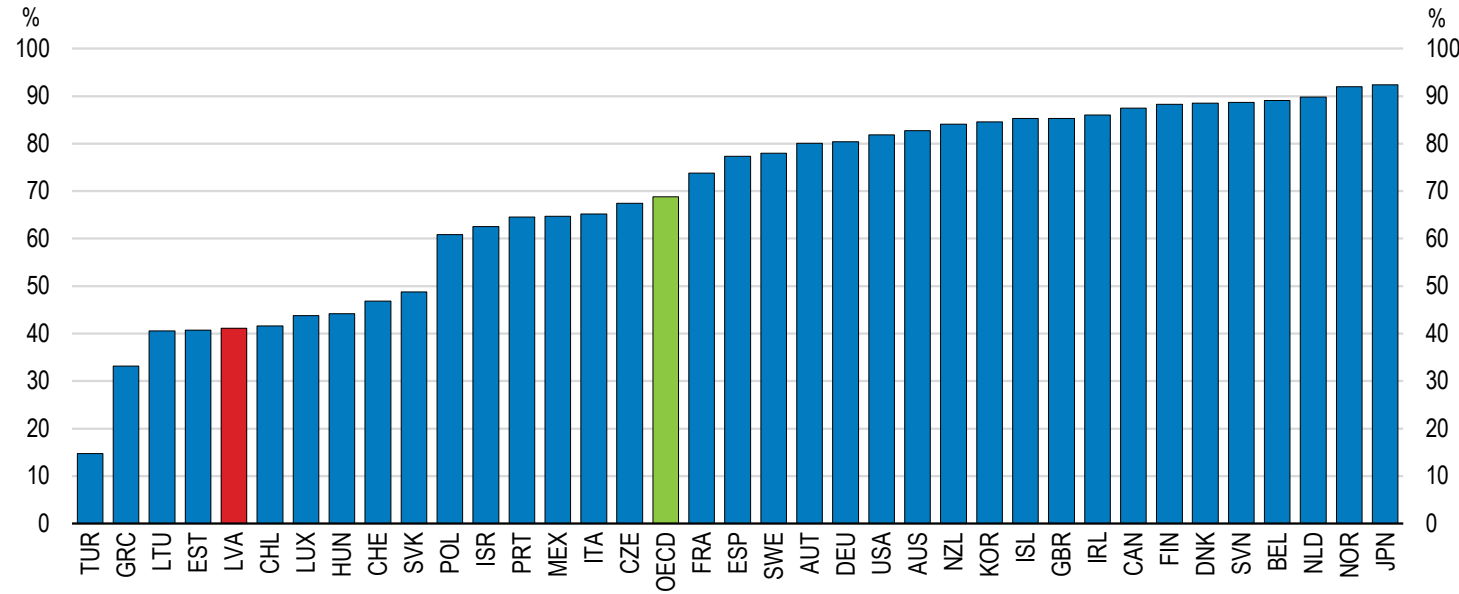

Note: The recovery rate is calculated based on the time, cost and outcomes of insolvency proceedings and is recorded as cents on the dollar recovered by secured creditors. The calculation takes into account whether the business emerges from the proceedings as a going concern or the assets are sold piecemeal. The costs of the proceedings are deducted. The value lost as a result of the time the money remains tied up in insolvency proceedings is also deducted. The recovery rate is the present value of the remaining proceeds.

Source: World Bank, Doing Business 2019 database.

StatLink iㅔs https://doi.org/10.1787/888933926908 


\section{Building a transparent and efficient insolvency regime}

An efficient insolvency regime plays an important role in improving the resource allocation in Latvia. It would contribute to higher credit growth by raising the debt recovery rate and facilitate the exit of unproductive firms, so that scarce resources like skilled workers can be reallocated to more productive firms (Adalet-McGowan et al., 2017).

Latvia's insolvency regime was plagued by fraudulent behaviour due to low penalties for abusers and low accountability of insolvency administrators (OECD, 2017a). Improving transparency of insolvency proceedings has thus been high on the political agenda over the past decade. A comprehensive reform simplified the insolvency administration and introduced more stringent requirements for the certification and selection of insolvency administrators as well as the disclosure of their income and assets.

\section{The insolvency framework needs further improvement}

The OECD indicator of insolvency regime, which covers a wide range of measures that facilitate smooth exit of non-viable firms and debt recovery aside those increasing the transparency of insolvency proceedings (Adalet McGowan et al., 2017), indicates that Latvia can further enhance the efficiency of its insolvency regime by incorporating some best practices among OECD countries (Figure 17).

Figure 17. The insolvency regime could be more efficient

The OECD insolvency regime indicator, 2016

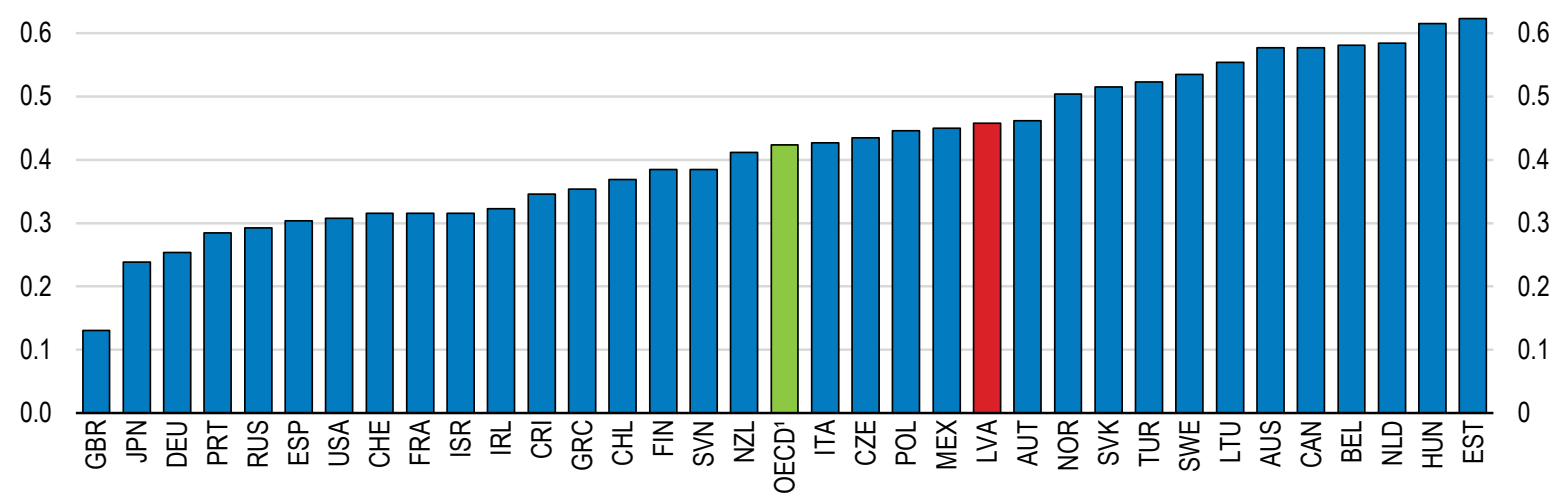

1. Unweighted average of available countries.

Note: A higher value corresponds to an insolvency regime that is most likely to delay the initiation of and increase the length of insolvency proceedings. Composite indicator based on 13 components: time to discharge; exemption of assets; early warning mechanisms; pre-insolvency regimes; special insolvency procedures for SMEs; creditor ability to initiate restructuring; availability and length of a stay on assets; possibility and priority of new financing; possibility to 'cram-down' on dissenting creditors and dismissal of management during restructuring; degree of involvement of courts; distinction between honest and fraudulent entrepreneurs and the rights of employees. For more details, see Source.

Source: Adalet McGowan, M., D. Andrews and V. Millot (2017), "Insolvency Regimes, Zombie Firms and Capital Reallocation”, OECD Economics Department Working Papers, No. 1399

StatLink त्गा5 https://doi.org/10.1787/888933926927

For instance, swift initiation of preventative restructuring can prevent the liquidation of viable firms that are experiencing financial distress. Delaying these procedures reduces the chance of survival and is likely to lower the liquidation value of failing firms, resulting in low debt recovery (Adalet McGowan and Andrews, 2018). In Latvia unlike in other OECD 
countries, creditors are given the right to initiate liquidation but not restructuring. The government should consider endowing creditors with this right, considering that firm managers may not initiate restructuring sufficiently early. Indeed, they often need to be nudged by creditors to initiate the proceedings. At the same time, adequate conditions must be attached to the initiation. In the United Kingdom, where both the debtor and creditors can initiate restructuring, the proceedings can only begin when the initiator can convince the court that the firm is or likely to be insolvent, and that the restructuring is likely to allow the firm's rescue or to achieve a better result for creditors than a liquidation. If the liquidation cannot be avoided, the restructuring is approved only if it ensures an orderly distribution of the proceeds from the sale of the firm's assets to creditors (Eurofound, 2017a).

It is equally important that firms facing risks of insolvency take adequate measures at an early stage, so that they can avoid entering insolvency proceedings in the first place. Latvia's insolvency regime includes a pre-insolvency regime that allows out-of-court settlement, such as a voluntary agreement to reduce debt payments. However, at that stage, the insolvency proceedings can only be avoided if all creditors agree to keep the company going (OECD/European Commission/ETF, 2014). The government should introduce earlywarning mechanisms, like the one provided in Denmark whereby entrepreneurs can receive a state-funded confidential assessment of the viability of their firm and support from experts to turn around a company facing potential risks. Such a service would be particularly useful for Latvian firms because they are often small and not professionally managed, and therefore more exposed to risks of financial distress from bad managerial decisions.

High fees such as insolvency deposits and complex procedures associated with insolvency proceedings can discourage small firms from filing for insolvency. Court fees to start judicial proceedings in Latvia are higher than in other European countries (European Commission, 2018c). Furthermore, the provision of legal aid is limited in terms of financial resources and scope (CEPEJ, 2018). The income threshold for the eligibility for legal aid is more than $20 \%$ below the poverty line, a level that is lower than in other European countries, including Estonia and Lithuania (European Commission, 2018c). Access to legal aid is thus limited for small business owners. As a result, small firms with very low profitability may linger in the market, preventing the reallocation of resources (Adalet McGowan et al., 2017). In order to improve access to the insolvency regime, the government should consider easing the eligibility for legal aid and allowing administrative expenses of insolvency proceedings to be paid in instalments.

\section{Improving the quality of court decisions}

Measures to improve the quality of the judicial system are a necessary complement to the reform of insolvency administrative procedures. The reorganisation of the judicial map completed in 2018 has reduced the number of courts by $70 \%$. The resulting concentration of judges into larger courts will allow some of them to specialise in insolvency cases, which could help strengthen expertise and ensure more uniform and predictable judgements (OECD, 2018a). There is also an ongoing large scale training programme for judicial staff aimed at enhancing capabilities in managing judicial processes and professional knowledge.

Nevertheless, the judicial system's capacity to deal with professional misconduct by judges has been a concern (European Commission, 2018b). Disciplinary investigations rarely result in sanctions, suggesting that judicial discipline has weak deterrent effects (CEPEJ, 
2018). The credibility and effectiveness of judicial discipline can be reinforced by improving the system of investigating disciplinary offences committed by judges (CEPEJ, 2018). Currently, complaints are first received by different judicial bodies including the Judicial Ethics Committee, the Minister of Justice, or presidents of courts, which carry out preliminary investigations. Those bodies then report to the Judicial Disciplinary Committee (JDC). However, investigation approaches can differ among them and there are considerable uncertainties about how the cases are handled or whether they are neutral in term of investigating judges. In order to ensure consistency in the judicial disciplinary process, the government should consider establishing a judicial inspectorate, as is common in other OECD European countries. In addition, the deadlines for dealing with disciplinary cases should be lengthened in light of international best practices. In particular, the time limit of three months for running investigations could be extended for complex cases to ensure high-quality decisions by the JDC.

\section{Diversifying credit supply}

Bank loans remain the major channel of credit supply in Latvia. Non-bank loans are increasing, but account for only $19 \%$ of total domestic loans to the non-financial private sector. The value of outstanding loans of non-bank financial institutions was five times smaller than that of credit institutions (Bank of Latvia, 2018). Furthermore, domestic banking is dominated by large foreign-owned banks. This may be contributing to the relatively high reluctance of SMEs to apply for bank loan (see Figure 14), as large credit institutions often apply more stringent requirements for lending applications (Bank of Latvia, 2017), and foreign-owned banks tend to engage less in relationship lending (Stein, 2002; Havrylchyk, 2012; Havrylchyk and al., 2012). A potential issue in Latvia could be that subsidiaries of foreign banks make little efforts to acquire tacit information on firms' competitiveness through repeated interactions, as they are subject to the lending policy of parent banks, which bases the lending decision on corporate financial reports and lending history (Rupeika-Apoga and Solovjova, 2017).

Strengthening the role of relationship lending can support SMEs' financing and improve stability of business finance, not least during credit cycle downturns (Beck et al., 2015; Banergee et al., 2017). For instance, credit unions (e.g. not-for-profit member-owned financial cooperatives funded largely by voluntary member deposits) provide credit to small firms that lack credit history, liquidity and physical collateral (Mazure, 2011). There are 33 credit unions operating in Latvia, mostly in rural areas. They are however minor players, with total assets amounting to only EUR 29.3 million in 2017. However, expanding their role would require subjecting them to stricter prudential regulations.

Crowdfunding is another promising alternative source of finance, but it remains, for now, mainly focused on providing consumer loans to foreign borrowers (Bank of Latvia, 2018). To support the development of a crowdfunding market and to increase its role in financing the investment of Latvian firms, licencing and transparency requirements comparable to credit institutions should be introduced. Furthermore, information on creditors' rights and risks should be provided to reinforce protection of investors. Strengthening investors' confidence would help platforms scale up and entrepreneurs to access a wider base of funders.

\section{Strengthening start-up and growth financing}

Small innovative firms often lack sound collateral and an established credit history needed to access bank loans. They therefore need start-up and growth financing to finance their 
investment. The availability of seed and early-stage financing is found to help firms adopt digital technologies, across OECD countries (Andrews et al., 2018).

The government established a single development financing institution Altum, offering a wide range of start-up and growth financing through public loans, credit guarantees, and microfinance measures. In 2018, conditions for access to loans for small new businesses have been relaxed to broaden the scope of clients. Such steps are welcome although the government should be mindful of the risk that generous public loans crowd out private riskoriented finance.

Venture capital funds have grown fast in Latvia in the past few years, thanks to the injection of substantial public financing. Recent policy action focused on developing pre-seed, seed and venture stage capital, as previously available measures were dominated by later-stage growth financing. The absolute size of the venture capital market however remains low (Figure 18), due to a difficulty in identifying good investment projects. The development of venture capital should be further enhanced by reducing administrative burdens, for instance by simplifying registration procedures and reporting obligations for running a fund. Plans to reduce information requirements for venture capital funds while remaining in line with EU regulation are thus welcome.

Figure 18. Venture capital investments remain low

Venture capital investments, \% of GDP, 2017 or latest available year

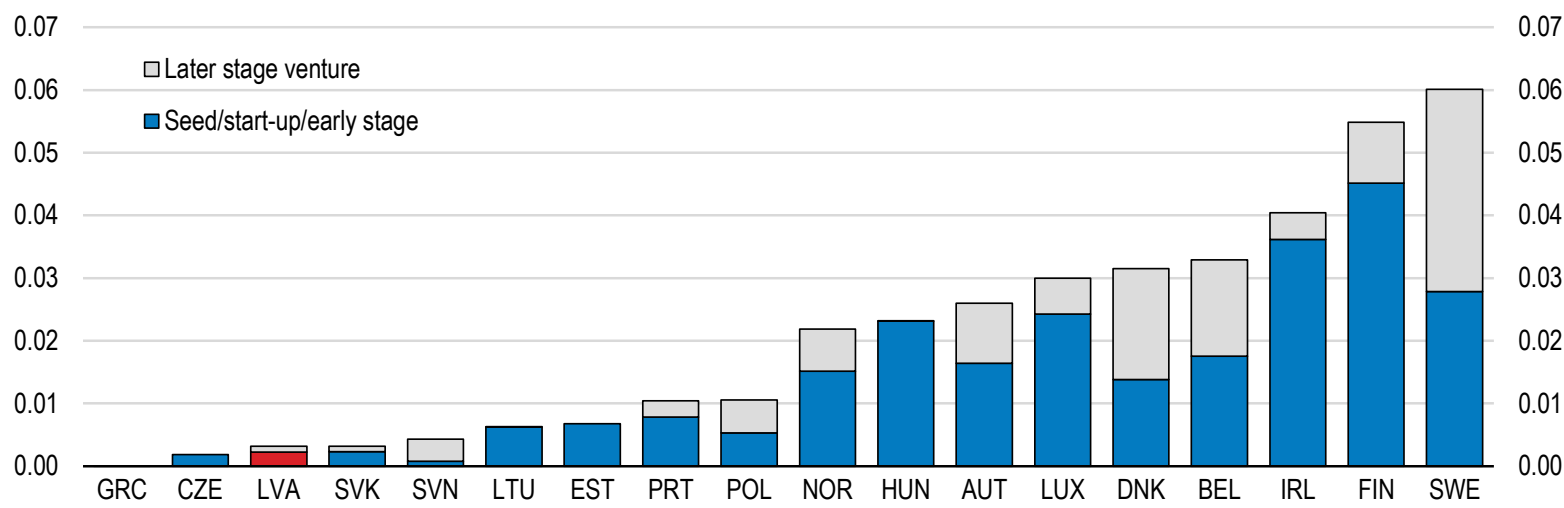

Source: OECD (2018), Entrepreneurship at a Glance Highlights 2018.

StatLink त्गाड़ https://doi.org/10.1787/888933926946

\section{Enhancing competition}

\section{Competition can be strengthened in some sectors}

A healthy degree of competition, through vigorous market entry or import penetration, can encourage innovation and corporate efforts to trim inefficiency (Aghion et al., 2005; Pavcnik, 2002). Also, more competition friendly regulatory settings are associated with a higher share of firms adopting digital technologies (Andrews et al., 2018). More competitive markets facilitate the allocation of resources to the most productive firms, allowing innovative firms to grow faster while promoting the exit of unproductive firms (Arnold et al., 2011).

Overall, Latvia's regulatory settings are competition friendly, and administrative burdens for starting up a company are among the lowest in the OECD (Figure 19). This supports strong business dynamics with firms entering and exiting the market accounting for $16 \%$ and $9 \%$ of the total number of firms in 2016, whereas the EU average of such ratios was 
$9 \%$ and $7 \%$ respectively according to Eurostat data. On the other hand, state-involvement in network sectors is stronger than the OECD average, mainly due to the prevalence of state-owned enterprises (SOEs).

Latvia's mark-ups are higher than in many advanced OECD economies (Figure 20). Markups are particularly high in the electricity and gas sectors (Figure 21). In the electricity sector in particular, state-owned enterprises (SOEs) retain a large market share, despite the liberalisation of the retail markets and unbundling of network providers from suppliers (European Commission, 2018b).

Figure 19. Regulatory settings are competition friendly overall

OECD 2018 Product Market Regulation indicator and selected components (provisional)

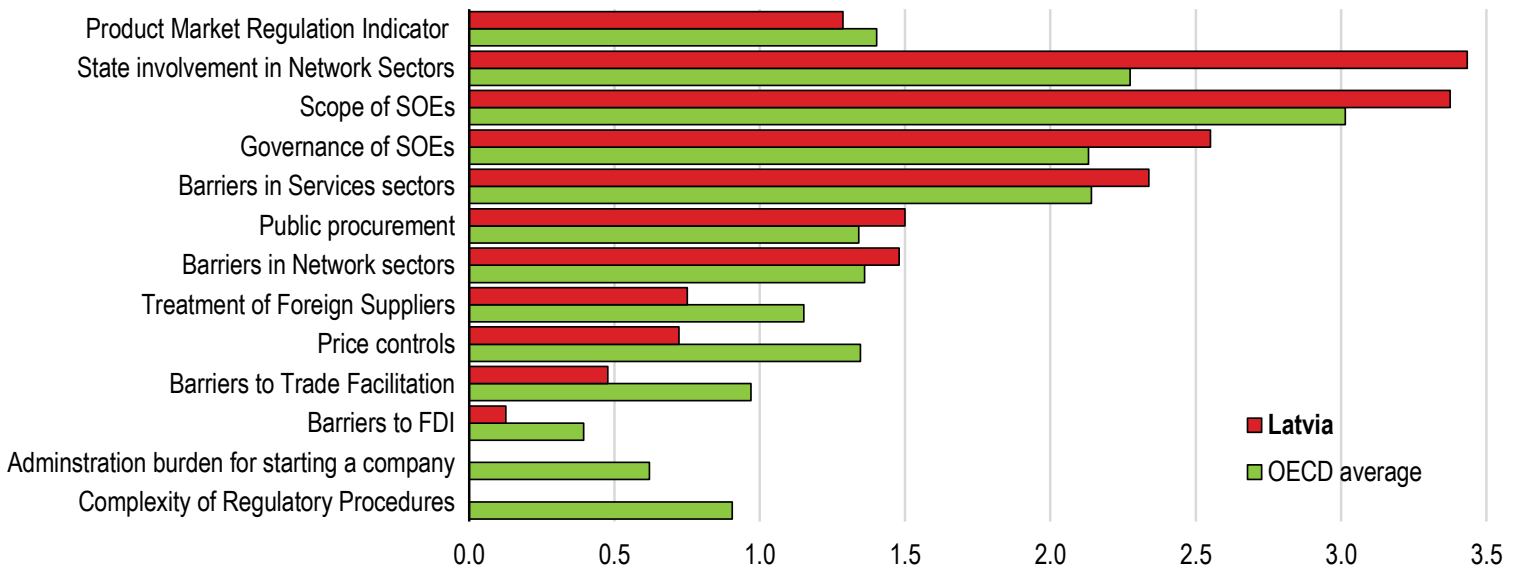

Note: The OECD average values are subject to change.

Source: OECD (2018) Product Market Regulation Indicators (preliminary).

StatLink त्राज़ https://doi.org/10.1787/888933926965

Figure 20. Mark-ups are relatively high in Latvia

Mark-up, averaged over 2011-2015

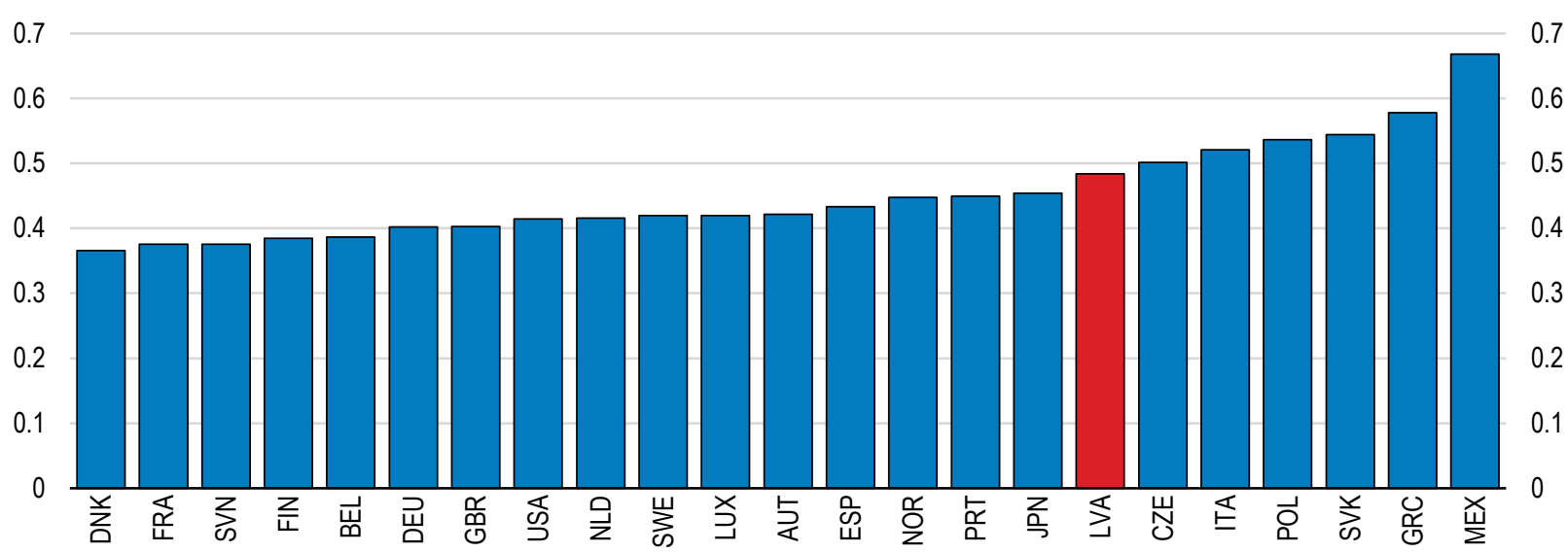

Note: Mark-ups are computed from the OECD STAN industry-level database, as the ratio where the numerator is the value added subtracted by the labour and capital costs and the denominator is the value added.

Source: Égert, B. and A Vindics (2019) "Mark-ups and product market regulation in OECD countries: what do the data whisper?" OECD Economics Department Working Paper, forthcoming.

StatLink जiाs https://doi.org/10.1787/888933926984 
Figure 21. Mark-ups are higher in sectors with many SOEs

Mark-ups by sector in Latvia, 2015

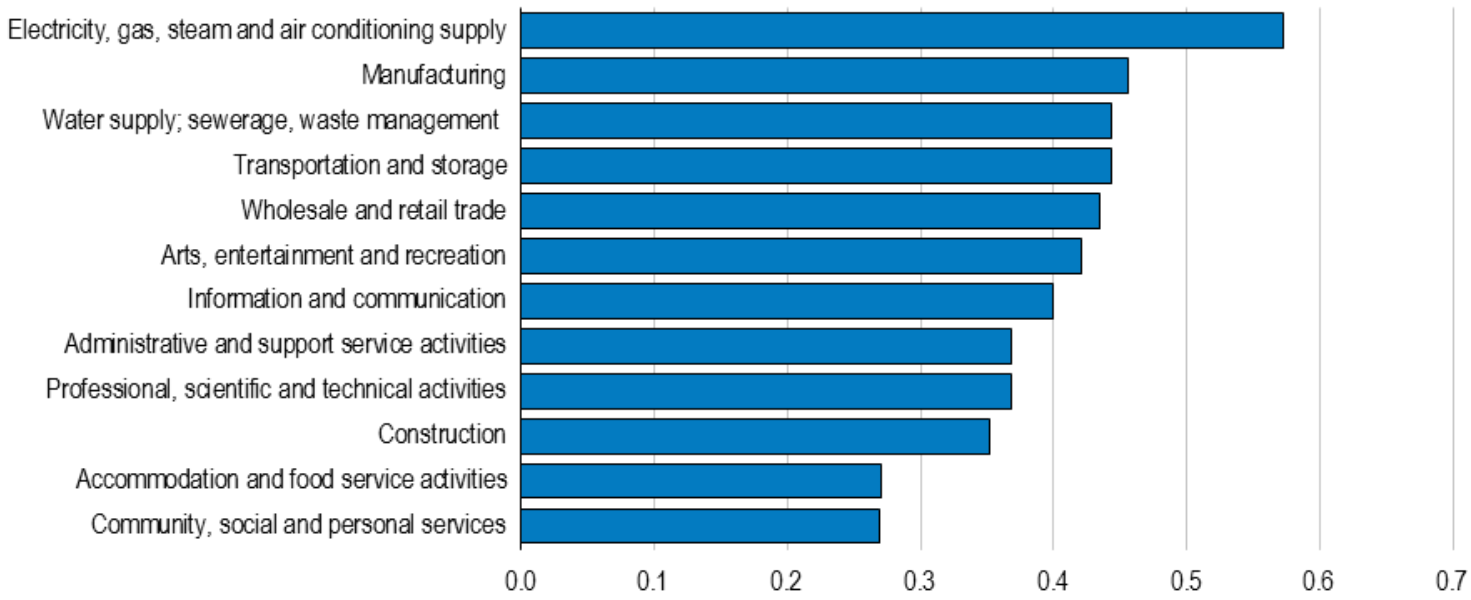

Note: Mark-ups are computed from the OECD STAN industry-level database, as the ratio where the numerator is the value added subtracted by the labour and capital costs and the denominator is the value added.

Source: Égert, B. and A Vindics (2019) "Mark-ups and product market regulation in OECD countries: what do the data whisper?" OECD Economics Department Working Paper, forthcoming.

StatLink त्गाड़ https://doi.org/10.1787/888933927003

\section{Ensuring fair competition between state-owned and private enterprises}

\section{Reducing state ownership}

State-owned enterprises (SOEs) in Latvia account for a larger share of the economy than in many other OECD countries (OECD, 2017b). At the end of 2017, they comprised about $5.6 \%$ of turnover and 5.4\% of employment in Latvia's business sector. Such shares are higher if enterprises owned by municipalities are included. The largest SOEs by assets are found in electricity, transportation and telecommunication, where they have an important economic weight. Mark-ups tend to be high in such sectors (Figure 21). SOEs can distort competition if they have softer budget constraints and thus weaker incentives to increase efficiency. Reducing state ownership where it is sufficiently justified, would promote competition. Also, the full independence of the competition authority and sector regulators that oversee SOEs needs to be ensured.

Latvia introduced a new law regulating SOEs in 2015. Whenever necessary, but no less frequently than every five years, shareholder ministries must submit a re-assessment of the rationale for state ownership. However, the guidelines explaining the criteria for state ownership are vague and the first assessment in the end of 2015 and in 2016 resulted in little reduction of state ownership (OECD, 2017b). The Cross-Sectional Coordination Centre (CSCC), examines the assessment submitted by the line ministries and provides its opinion. However, the Competition Council and stakeholders such as business associations play only an advisory role. The government should use the forthcoming assessments as an opportunity for careful analysis of options for cutting back state ownership. More rigorous guidelines should be adopted on the scope of market failures that justify state ownership, and the services, goods and properties that are "of strategic importance" and thus need to 
be supplied by SOEs. The government should engage in a transparent discussion involving social partners and the Competition Council in producing the new guidelines.

The holder of state capital shares submits to the Cabinet of Ministers the assessment of state ownership in the respective enterprise and the conformity of such ownership with conditions set out in the law. The rationale for state ownership is decided at the Cabinet of Ministers meeting. The Coordination Institutional Council (CIC) may also provide recommendations on the assessment and participate at the meeting, if its opinion is necessary for decision making or it has objections. These recommendations are not binding, however. The CIC consists of the shareholding ministries, representatives from the local governments, employers' associations and trade unions. To ensure that recommendations do not violate the principle of competitive neutrality, the Competition Council should be included in the CIC as a full member.

\section{Improving the governance of SOES}

When the privatisation of commercial activities by SOEs is not possible, the governance of SOEs should be strengthened further. The SOEs in Latvia are potentially exposed to undue political influence, due to a lack of supervisory boards (OECD, 2017b). Since 2015 the 12 largest commercially-oriented SOEs have a supervisory board, but the shareholding ministries have a strong influence in nomination committees. Giving the CSCC the authority to lead the nomination committee would strengthen the independence of the selection process.

Smaller SOEs still lack supervisory boards and are therefore governed by the shareholding ministries, although those mostly are non-commercially oriented enterprises or enterprises with mixed objectives. As recommended by the OECD Corporate Governance Accession Review of Latvia and the 2017 Economic Survey, the government should introduce supervisory boards at all commercially-oriented SOEs, regardless of their size, to improve their governance (OECD, 2017b). Such a provision is currently foreseen for medium-sized companies in a draft law.

Municipalities in Latvia are often eager to set up their own companies rather than promoting the entry of private firms into municipal services (OECD, 2018b). There is a concern that municipalities distort competition in public procurement by including conditions that favour their own enterprises (FICIL, 2018). Municipal enterprises account for $40 \%$ of the employment by all SOEs (European Commission, 2018b). While they are to a large extent subject to the same law that regulates SOEs, they are not monitored by the CSCC. A framework to keep in check the establishment and the scope of municipal enterprises and monitor their corporate governance needs to be strengthened, for instance, by extending the monitoring of large commercially-oriented municipality-owned enterprises by the CSCC.

\section{Bolstering competition law enforcement}

\section{Strengthening the independence of the Competition Council}

An effective competition authority is vital to ensure competitive product and services markets, which in turn is central to efficient resource allocation. Although the Competition Council is granted independence by law to enforce the Competition Law, it remains a suborganisation of the Ministry of the Economy. The Chairperson and the Council members are appointed and can be removed at the Minister of Economy's discretion. This increases the risk that the Competition Council may be subjected to the influence of shareholding 
ministries when investigating anti-competitive behaviour by their SOEs, given ministries' interest in raising revenue through their companies. For instance, $90 \%$ of the profit of the electricity network operator is transferred to the government (European Commission, 2018b). At the same time, there have been large withdrawals from this particular SOE's equity to compensate for government decisions related with changes in renewable energy policies.

Strengthening the Council's independence could improve the confidence of market participants in fair conditions for competition, and thus incentives to invest, grow and improve efficiency. It would also improve the Council's position when negotiating with potential infringers about remedies. The Competition Council should also report directly to the parliament through its annual reports, as done in other OECD countries such as France and Germany (OECD, 2017b).

\section{Endowing the Competition Council with adequate resources}

A sufficiently large, well-trained and specialised staff is essential for the effective enforcement of competition law and competition advocacy. However, the budget allocated to the Competition Council is smaller than those of authorities in countries of a similar size and disproportionally smaller compared to those in larger countries (Table 1). The Competition Council has struggled to fill vacancies for specialists with the right qualifications, partly because it cannot offer competitive compensation. Wages are below those of the private sector and other law enforcement agencies and regulators, causing a steady drain of staff. In 2017, there were 51 positions in the Competition Council, but only 44 were filled, and staff turnover was relatively high (Competition Council, 2018). Although a legislative step in 2017 enabled the Council to offer more competitive remuneration, the Council did not receive the additional funding needed to increase wages (Competition Council, 2018).

Table 1. Resources allocated to the competition authority are low

Data from 2017, unless otherwise indicated

\begin{tabular}{lccc}
\hline & $\begin{array}{c}\text { Non-administrative } \\
\text { staff focused on } \\
\text { enforcement and } \\
\text { mergers }\end{array}$, 2017 & $\begin{array}{c}\text { Budget } \\
\text { (EUR million) }\end{array}$ & $\begin{array}{c}\text { Population } \\
\text { (Millions) }\end{array}$ \\
\hline Latvia & 33 & 1.2 & 1.9 \\
\hline Denmark & 58 & 11.2 & 5.8 \\
Finland $^{2}$ & 45 & 10.6 & 5.5 \\
Lithuania $_{\text {New Zealand }}^{3}$ & 43 & 2.3 & 2.8 \\
Slovenia & 94 & 11.2 & 4.8 \\
\hline
\end{tabular}

1. Excludes staff involved in advocacy and support-staff. 2. The Danish and Finnish competition authorities also integrate consumer protection functions. 3. New Zealand Commerce Commission "General Markets" budget which covers both competition and consumers.

Source: OECD.

The Council relies on the Ministry of Economics to acquire its annual budget. To secure the Competition Council's operational freedom, it is desirable that it be financed through an autonomous, stand-alone budget, as is the case in several OECD and EU countries. There are also several ways for competition authorities to fund themselves. Some jurisdictions impose a small duty on the amount of the initial share capital, and of each 
capital increase by limited liability companies (such as Greece), while others may keep a share of the fines imposed, as in Portugal (OECD, 2018a). Since 2016, the revenue from the levy on merger notifications has been allocated to the Competition Council. While this is welcome, more needs to be done to alleviate the resource shortage.

\section{Strengthening the authority of the Competition Council}

Unlike competition authorities in some other jurisdictions, the Competition Council has limited statutory powers to intervene against public bodies including municipalities, to ensure equal conditions for competition for state-owned and private businesses. A new amendment to the Competition Law grants the Council the right to impose legal obligations and penalties up to 3 per cent of turnover on municipal enterprises and SOEs to redress their commercial activities that violate competitive neutrality. However, the Council will need to first attempt to negotiate for a solution, and will not be able to fine municipalities. Furthermore, it will not be given the right to effectively intervene in public policies that distort competition.

\section{Strengthening skills}

The difficulty in hiring skilled personnel is one of the most important impediments to firm growth and investment in Latvia. Poor access to skills holds back the capacity of Latvian firms to innovate, adopt advanced technologies and to participate in global value chains, all of which are important for productivity growth (OECD, 2017a). In particular, the severe shortage of digital skills constrains the use of digital technologies in corporate activities like supply chain management, which would boost the productivity of Latvian firms Figure 22). Shortages of qualified personnel are also considered as one of the largest barriers to capital investment by Latvian firms, suggesting that making the best of new equipment requires advanced skills (European Investment Bank, 2018).

Figure 22. The shortage of digital skills is severe

The share of individuals with basic or above basic digital skills, \%, 2017

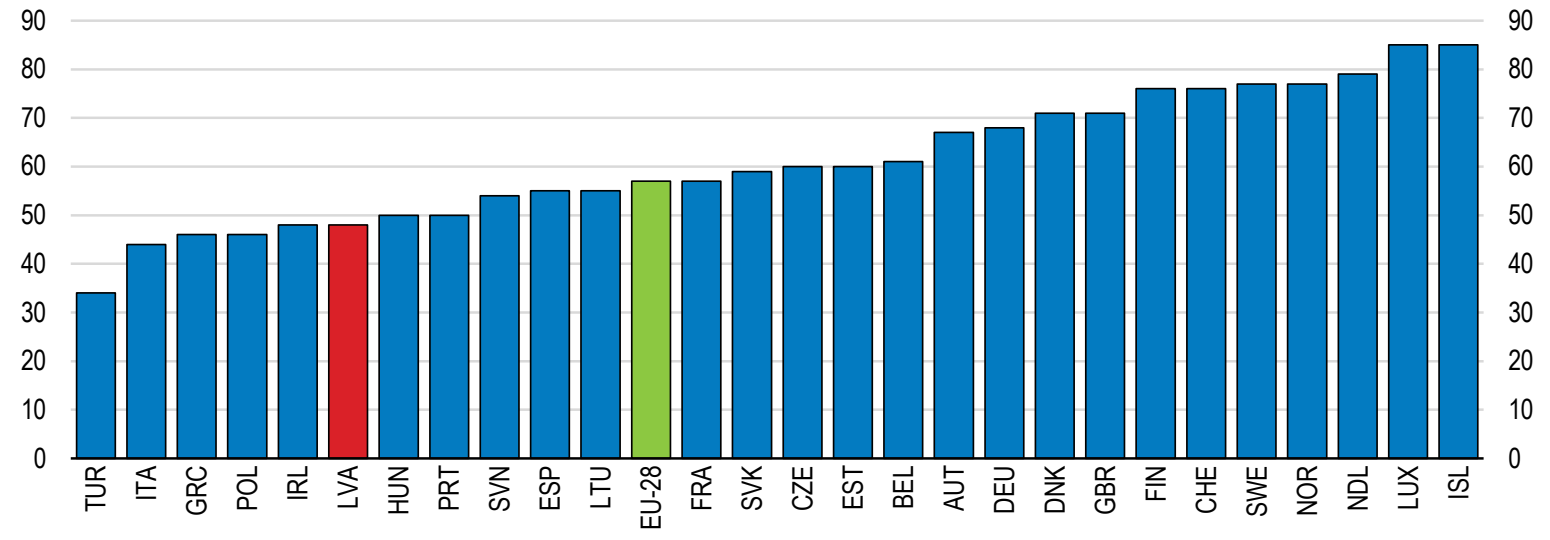

Source: Eurostat.

StatLink त्ञाIS https://doi.org/10.1787/888933927022

The emigration of skilled workers exacerbates shortages: highly educated workers accounted for $40 \%$ of net outward emigration between 2009 and 2016 (European Commission, 2018b). To counter this, Latvia needs to attract talent and skills from abroad, 
in addition to enhancing upskilling and retraining of the labour force. In 2018, the government eased the labour market tests for the hiring of foreign skilled workers in 237 professions where severe skills shortages are foreseen. More can be done to increase the inflow of foreign skilled workers. The government can consider enrolling those workers in the public health insurance scheme, so that they do not need to purchase private health insurance at an additional cost. It can also reduce the scope of occupations subject to Latvian language proficiency requirements (OECD, 2017a). Foreign students graduating from Latvian universities could benefit from the simplified labour market test for skilled foreign workers, or be exempt from labour market tests.

Severe skill shortages are also due to skill mismatches. 35\% of Latvian workers report that the expertise required at work does not match the field of their study (Figure 23). The Ministry of Economics estimates that the supply of personnel in natural sciences, mathematics and information technology will fall short of demand by $20 \%$ in 2025 (Ministry of Economics, 2018). A similar magnitude of mismatch is foreseen in engineering, manufacturing and construction as well. Yet, tertiary education graduates have been concentrated in social science fields (OECD, 2016). Addressing skills mismatches requires increasing the responsiveness of education and training to changing labour market demand and providing students and workers with the most relevant skills.

Figure 23. Skill mismatches are large

Field-of-study mismatch, \% of employed aged 15-64, 2016

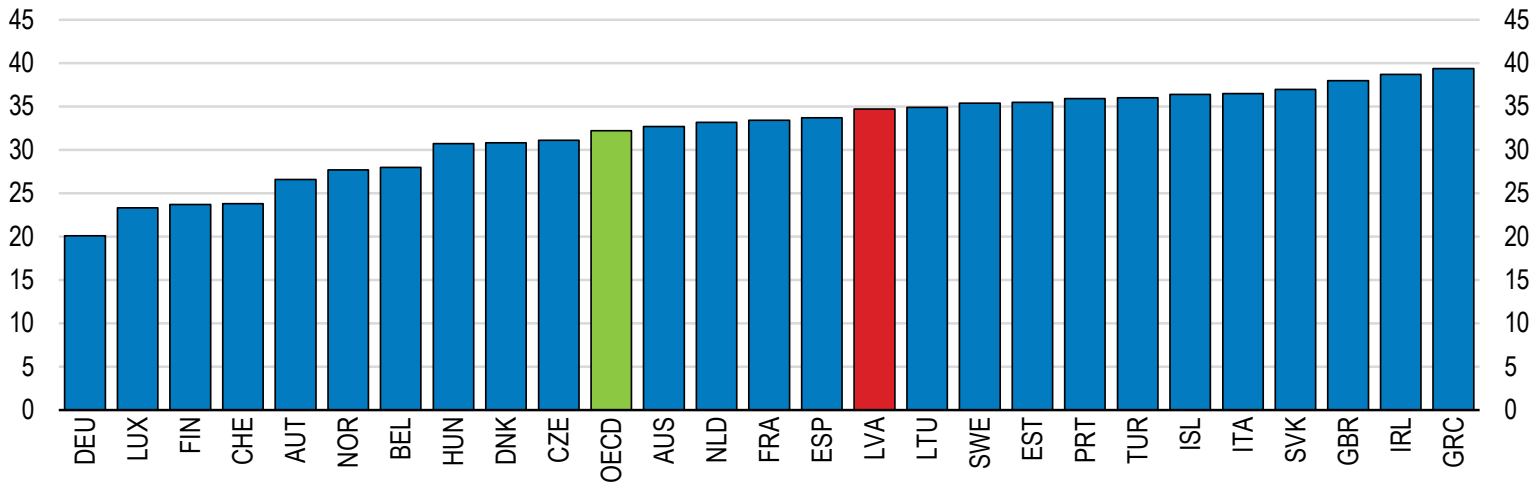

Note: Field-of-study mismatch arises when workers are employed in a different field from what they have specialised in.

Source: OECD, Skills for Jobs database.

StatLink त्ञाIs https://doi.org/10.1787/888933927041

The Latvian population needs to be endowed with solid cognitive and non-cognitive skills to adapt to fast changes in labour market needs. Improving access to high-quality early childhood and primary education would contribute to developing the learning ability and adaptive capacities of Latvian children throughout their lives (OECD, 2017d). Furthermore, the urban-rural divide in PISA scores needs to be addressed (OECD 2018c). Fewer resources are devoted to rural schools and shortages of qualified teachers have emerged, due to an ageing teaching workforce and unattractive working conditions (OECD, 2016). Higher remuneration and better career prospects should be offered to teachers, in particular in rural schools with many struggling students. Accelerating the ongoing consolidation of the school network could help raise resources for this. 


\section{Engaging more firms in vocational education and training}

During the last decade the government has made important progress in upgrading the content of vocational education and training (VET). This includes developing new occupational standards and qualifications for a wide range of professions, as well as modular programmes and qualification exams that correspond to those standards (OECD, 2017a). The social partners participate in such reforms through the Sectoral Expert Councils (SECs), which includes representatives of the Latvian Employers' Confederation (LDDK), of the Free Trade Union Confederation of Latvia (LBAS) and of relevant ministries. The SECs plays a central role in developing new programmes and evaluating the labour market relevance of curricula. Such close involvement of social partners is welcome as it is essential for the formulation of curricula, particularly in vocational education and training (Box 2).

However, there is a concern that SECs are not representative enough of all stakeholders that need to be involved. Members of the Latvian Employers' Confederation (LDDK) represent firms employing $44 \%$ of workers, but small firms are weakly represented (European Commission, 2018b), probably because membership of employers association is not compulsory (Eurofound, 2017b). Union coverage in Latvia is also low. Members of the Free Trade Union Confederation of Latvia (LBAS) are likely to have accounted for only $11 \%$ of total employees in 2016 (Eurofound, 2017b). Further efforts are needed to engage under-represented small firms in VET programme design.

The government has also improved the implementation of VET by consolidating VET schools and gradually upgrading VET schools with more than 500 students into Vocational Education Competence Centres (VECCs). VECCs are tasked with disseminating the latest VET programmes and providing pedagogical assistance to other VET schools, providing adult education and accrediting professional competencies acquired through informal trainings (OECD, 2016). The VECCs are certified by the government as providing excellence in teaching quality and act as regional hubs for collaboration with employers. The 22 VET schools currently certified as VECCs receive additional financial resources. While the majority of the 46 VET schools are funded by the central government, 6 are municipality funded (one of which is certified as VECC) and 8 are private. To coordinate the provision of training programmes and ensure that the upgraded VET curriculum is implemented throughout the country, VECCs could be giving a stronger leadership role in their region for coordinating VET programmes.

\section{Box 2. Involvement of social partners in vocational education and training}

Strong involvement of the social partners, namely employer associations and unions, helps to ensure that the overall design of the vocational education and training (VET) system, the content of programmes, and the workplace training meet labour market needs. The level of such involvement varies considerably across OECD countries but is usually higher in countries with good representation of employers and employees and strong apprenticeship systems.

\section{Germany}

Employer associations and professional organisations define the content of advanced vocational examinations as well as the courses taught at the technical schools (Fachschule) (Fazekas and Field, 2013a). Business chambers organise advanced vocational examinations, contributing to the high quality of graduates' skills. Many employers provide financial support to employees attending postsecondary VET studies and/or allow 
time off work to attend courses. The chambers provide some grants to students in need and also provide preparatory courses. Enrolment in chambers is compulsory for firms. While this increases the costs of doing business, it addresses free-rider issues regarding the financing of training and exams.

\section{Austria}

The compulsory membership of firms and employees into the Economic Chambers and the Austrian Trade Union Federation facilitates markedly strong engagement of social partners in the post-secondary VET system (Musset, P., et al., 2013). Social partners have their own training institutions. The Economic Promotion Institute (Wirtschaftsförderungsinstitut) affiliated to the Economic Chambers provides education on management and corporate leadership to managers and training for specific sectors to apprentices. The Vocational Training Institute (Berufsförderungsinstitut) affiliated to the Austrian Trade Union Federation provides a wide range of education and trainings to employees as well as to the unemployed and those in risk of unemployment.

\section{Switzerland}

Employer and professional organisations define the content of professional examinations as well as VET programmes. They also regularly revise the professional qualifications which underpin examinations. Most employers support their employees during their VET studies financially and some employer associations provide grants to students in need. In some sectors, when firms are too small or too specialised to train an apprentice, alliances are created so that firms can provide training jointly. In 13 sectors, all firms are required to contribute to a fund that finances costs of apprenticeships (Fazekas and Field, 2013b).

\section{Expanding work-based learning}

An adequate combination of general knowledge taught at VET schools with work-based leaning is essential for ensuring high labour market relevance of VET programmes (OECD, 2010). Training at companies is also important for more effective adult education and training for the unemployed. Latvia's VET has been biased toward school-based learning, which constrained its labour market relevance (OECD, 2016). Work-based learning was introduced in 2013 and was expanded in mid-2017, when the government launched a programme financed by the European Social Fund. Yet, only a small share of VET students have participated so far. Furthermore, a large share of students in work-based learning is concentrated in sectors such as hotel and restaurant services and beauty services (Ministry of Education and Science, 2019). Addressing the severe skill shortages in sectors such as ICT and financial services requires an extension of work-based learning to the higher education level, including college, and involving more firms that can provide training in these areas.

The major challenge in expanding work-based learning in Latvia is the prevalence of small and medium-sized enterprises (SMEs), which often shy away from offering work placements due to the logistical difficulties and administrative costs involved. Also, because small firms are often more specialised than large firms, they may not have the capacity to teach all the skills students need to acquire (Kuczera, 2017). Encouraging SMEs to offer training jointly, as done in many OECD countries, would facilitate their participation in work-based learning. For example, in Germany, the lead firm that bears the overall responsibility for workplace training can outsource parts of the training to various partner firms (Poulsen and Eberhardt, 2016). Several small firms can also form a 
consortium to take on students. In Austria, firms that cannot fulfil certain standards for workplace training can form training alliances. They receive help from the Economic Chambers in finding partners (Kuczera, 2017).

In Latvia, joint work-based training is coordinated by the vocational education institutions, including VET Competence Centres, in partnership with the Latvian Employers' Confederation (LDDK). The VET schools place students in multiple firms and ensure that all required skills are acquired. But smaller firms may need more relief from administrative procedures to be persuaded to participate and they may need assistance when it comes to planning and implementing on-the-job training. Furthermore, VET schools who cooperate with participating firms to plan and design work-based learning need to take stronger measures to engage also with small firms and address their skill needs.

In Australia, Group Training Organisations (GTOs) employ apprentices and hire them out to firms that provide workplace training. The GTOs receive public funding as well as contributions from employers (Kuczera, 2017). A similar role could be played by the LDDK in Latvia or possibly another organisation that concentrates exclusively on assisting small firms. Such an organisation would also be an adequate platform to gather information about the skill needs of small firms and feed them back into the design of VET curricula and work-based learning.

The introduction of joint work-based learning should be coupled with efforts to raise awareness of its benefits. According to studies in other OECD countries, despite the initial costs and administration burden associated with providing work-based learning, the net benefits quickly turn positive $(\mathrm{OECD}, 2010)$. Conducting a rigorous cost-benefit analysis and advertising the results could encourage small firms to participate in the work-based learning scheme.

\section{Increasing financial support to VET students}

The graduation rate of VET students is considerably lower than that of students enrolled in general upper secondary education (OECD, 2018c). As highlighted in the 2017 Economic Survey of Latvia, the average level of financial assistance for VET students is very low. This increases the risk that students, especially those from low-income households, to leave schools before academic completion. Such early school leaving is undesirable even though it is often due to employment, because without a valid upper secondary degree students risk facing poorer wage progression later in their career. Also, they will have fewer options to continue training, for example, at university. Since 2017, a project funded by the European Social Fund provides students at risk of leaving school early with financial and material support, which is welcome. Yet, a more sustainable solution that is available for all lowerincome students would be desirable.

\section{Making tertiary education more responsive to labour market needs}

Labour shortages in ICT, engineering, and sciences are set to intensify over the next few years (Ministry of Economics, 2018). Extensive efforts have been made to increase the number of graduates in the Science, Technology, Engineering and Mathematics (STEM) fields. The government has reallocated a larger share of state-funded free study places from social science to STEM fields to attract students. The new higher education financing model includes performance-related components, which would allocate additional funding to universities that increase their share of students in STEM fields (OECD, 2016). Nevertheless, the share of graduates in STEM fields remained around 20\% between 2015 and 2017, which is lower than in other Baltic or some Central European countries (OECD, 
2017c). Also, their absolute number has not increased due to the overall decline in the number of students.

Unlike many other OECD countries, Latvia does not provide means-tested financial assistance to university students. This prevents students from poor households from pursuing studies at universities, even when they are eligible for free study places (OECD, 2017a). Introducing such financial assistance, first targeting STEM studies, would relax the financial constraints faced by those students and increase the number of STEM graduates.

Latvia is one of the few OECD countries where external stakeholders are not included in the governance boards of the higher education institution (Borowiecki and Paunov, 2018). External stakeholders are only involved in consultative bodies (the Conventions). Universities in Latvia are governed by the Senate elected by staff and students, and rectors act on behalf of the Senate to implement its decisions and strategy. Such traditional collegial governance holds back the ability of Latvian universities to respond swiftly and strategically to the changing economic and societal needs (European Commission, 2018d). Since 2017, the government has required higher education institutions to coordinate their development strategies and infrastructure investment plans with industry representatives. The government should consider including stakeholders such as industry and union representatives in universities' governing boards, as in many OECD countries. In most cases, industry representatives are from large firms, but in some countries such as Iceland and Ireland, representatives from SMEs also participate (Borowiecki and Paunov, 2018).

High quality tertiary education is central to providing a highly qualified workforce into the labour market. The accreditation and licensing system for study programmes in tertiary education has been improved, and the national accreditation agency was registered in the European Quality Assurance Register for Higher Education (EQAR) in 2018. On the other hand, an insufficient knowledge base has made it difficult for many Latvian students to complete a Bachelor's degree in STEM studies (Kuḷikovskis et al., 2017). To improve upon this, mandatory state exams in natural sciences were introduced at the end of upper secondary education.

\section{Improving the skills of the adult population}

\section{Enhancing the quality of adult education}

The government has expanded adult education programmes since 2017 using European Social Fund financing. Adult education is provided by diverse bodies, such as the central government, municipalities, craft and professional associations as well as private institutions. The government introduced a horizontal governance model in 2016, which involves relevant ministries, local governments and social partners. The Ministry of Education and Science is responsible for planning policies and improving the qualification of employed adults, whereas the Ministry of Welfare has responsibilities for endowing the unemployed with suitable skills. Adult education is also better targeted than before the 2016 reforms, as it focusses on occupations where significant skill shortages are foreseen in the labour market forecasts by the Ministry of Economics.

Private providers of non-formal education programmes that are not registered as education institutions are required to obtain a licence from the local government, which in some cases evaluates the content and qualifications of teachers. The scope and quality of adult education offered by municipalities vary considerably depending on their fiscal resources (OECD, 2016). Its quality can be enhanced by giving Vocational Education Competence Centres (VECCs) a stronger leadership role in planning the provision of adult training in 
their region in order to avoid duplication and strengthen synergies. This could include closing ineffective programmes or merging them with stronger alternatives. The pedagogical assistance provided by the VECCs to VET schools could be extended to adult education providers. The VECCs could also act as the platform for coordinating education programmes offered by VET schools and providers of municipality-funded training.

It is particularly important that adult education addresses the severe shortages of digital skills. Adult education should also help workers improve the ability to make the best of digital technologies. This includes advanced managerial skills, which are needed to lead organisational transformations that maximise the productivity gains from adopting digital technologies (Andrews et al., 2018). Relatively few Latvian firms have access to professional managerial skills (Figure 24), making such organisational changes challenging. The state-funded adult education programmes offer courses in ICT-related subjects (including the manufacturing of digital equipment), which were particularly popular. Developing advanced management courses for professionals at higher education institutions that can be attended part-time could improve the uptake.

Figure 24. Relatively few firms are managed by professional managers

Reliance on professional management, score from 1 (lowest) to 7 (highest), 2017-18

7

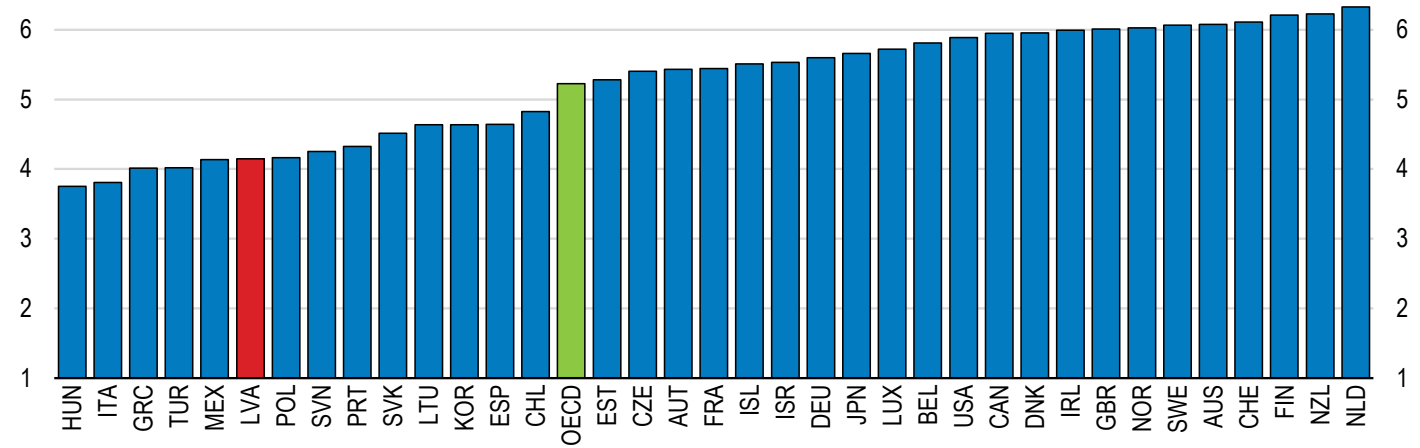

Note: Score based on responses to the question: "In your country, who holds senior management positions in companies? [ 1 = usually relatives or friends without regard to merit; 7 = mostly professional managers chosen for merit and qualifications]".

Source: World Economic Forum (2017), The Global Competitiveness Index Historical Dataset 2007-2017..

StatLink 제으 https://doi.org/10.1787/888933927060

\section{Promoting the participation in adult education}

The rate of participation in adult education in Latvia is lower than in many OECD countries (Figure 25), despite significant skill mismatches. As in many other countries, it is particularly low among workers with low educational attainment. In 2016, less than $3 \%$ of the working age population with less than lower secondary education attainment participated, while $11 \%$ of those with tertiary education attainment did (Eurostat, 2016). Some adult education programmes are targeted at the low-skilled. Yet, less than $20 \%$ of participants were low-skilled in the latest round of the programmes offered.

In countries with high levels of participation in adult education such as Switzerland, employers assume a large share of training costs, whether in the form of financial support for direct costs or of permission to make use of paid working hours (OECD, 2018d). Some countries, such as France and the Netherlands, endow workers with individual training accounts that provide them with rights to receive a certain amount of state-funded education 
and training. Although the government introduced regulation to provide financial support to employers granting additional education and training to employees as early as in 2012, the implementation of the support scheme was postponed several times. It is currently foreseen for the end of 2022. The government should implement such support earlier, perhaps focussing it on workers looking to acquire skills that are in short supply or on lowskilled workers. The financial support could also target the retraining of workers without qualifications or those that were engaged for some time in a job unrelated to their initial training, as in Germany (OECD, 2017e).

Figure 25. Participation in adult learning is low

Per cent of population aged 25-64 participating in education and training in the preceding four weeks, 2017

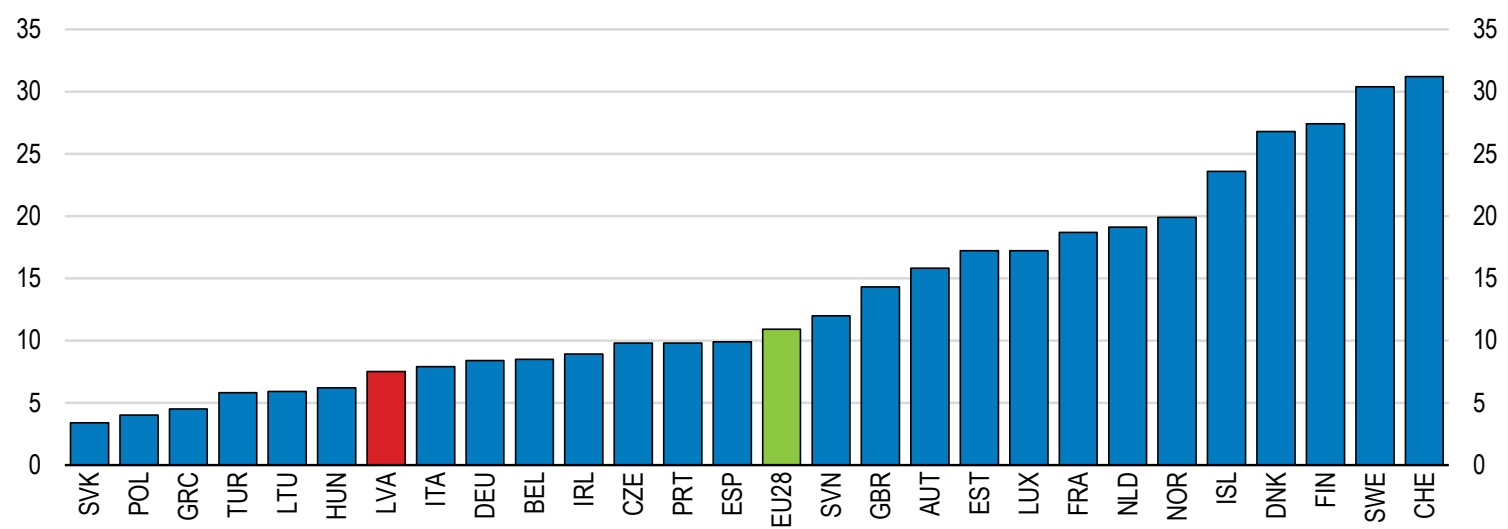

Source: Eurostat.

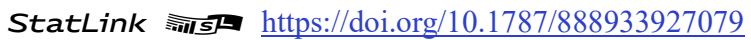

\section{Active labour market policies should receive more stable funding}

Latvia's active labour market policies (ALMPs) are characterised by low participation and spending compared to many other European countries (Figure 26). They have been refocused from public employment schemes to measures that promote labour mobility, and activation programmes for the long-term unemployed have expanded dramatically. A large share of ALMP participants benefits from training measures, which are effective in increasing the chance of finding employment (OECD, 2019b).

Competent caseworkers that direct unemployed persons into adequate support measures are key for the effectiveness of ALMPs. However, the State Employment Agency (SEA) is mainly financed by EU funds, which induced volatility in staff employment of the SEA every time a large EU funded ALMP programme expired. This risks undermining the effectiveness of ALMPs by increasing the caseload per caseworker, making it difficult for them to spend sufficient time per unemployed person (OECD, 2019b). Integrating the most effective ALMP measures into the national budget would stabilise the SEA's manpower.

The number of caseworkers should also be increased as caseloads can be high. Hiring more counsellors can be effective in intensifying counselling and reducing unemployment spells, as experience in Germany and the Netherlands has shown (Hainmüller et al., 2016; Koning, 2009). The government has reallocated the counsellors previously hired for an EU-funded project that expired recently to public employment services. However, increasing the net number of counsellors is difficult due to the cap on the number of government employees. 
Figure 26. Participation in active labour market policies is low
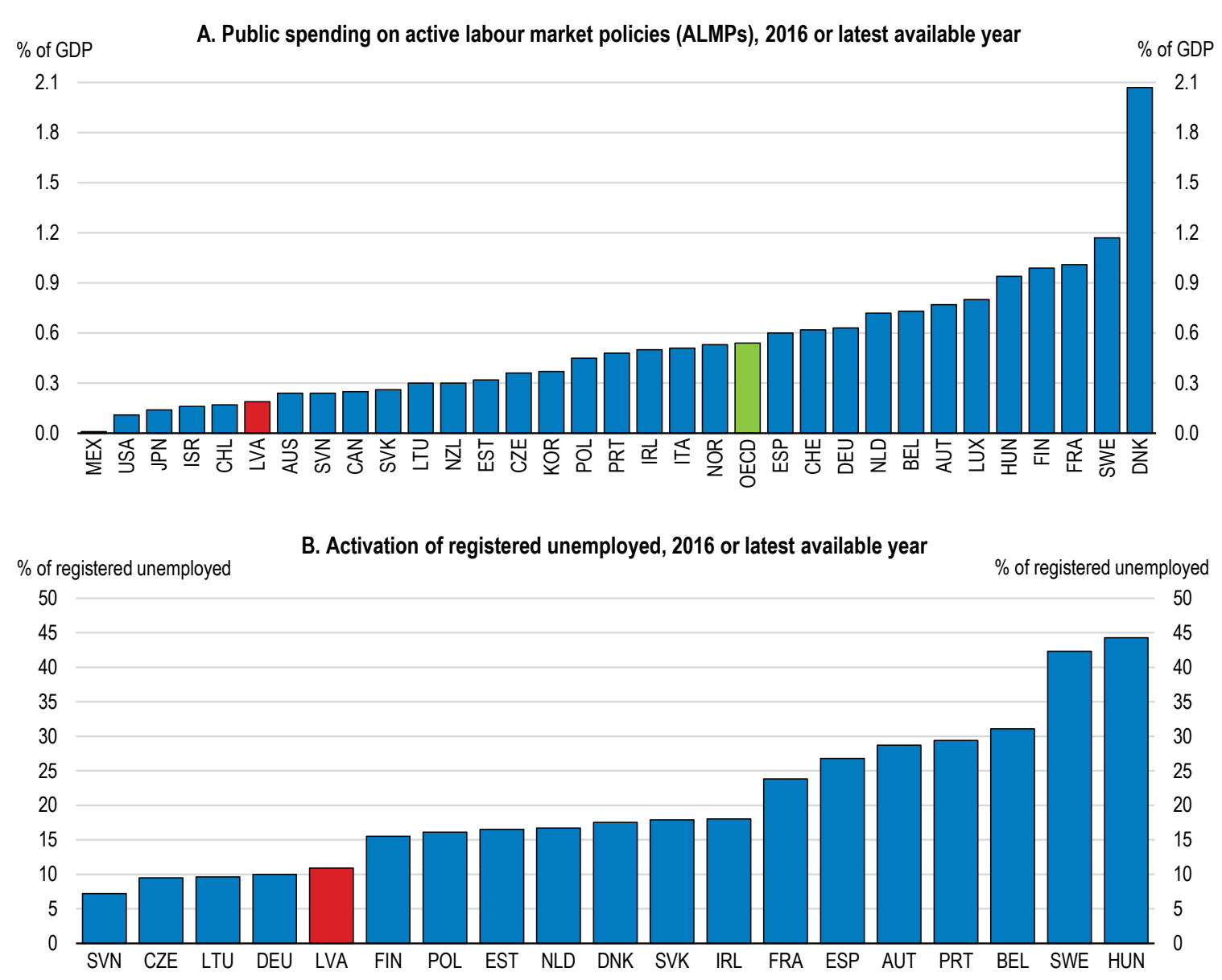

Note: Active policies include expenditure on the PES or other administration, training, employment incentives, supported employment, direct job creation and start-up incentives.

Source: OECD Labour Force Statistics; European Commission, Labour Market Policy database.

StatLink त्गा5म https://doi.org/10.1787/888933927098

\section{Strengthening innovation and knowledge transfer}

\section{Latvia's innovation performance is weak}

Innovation activity in Latvia is weak compared to many other OECD countries, especially in the business sector. At $0.14 \%$ of GDP, business-based research and development (R\&D) expenditure is among the lowest in the OECD. The share of Latvian SMEs engaging in product or process innovation or introducing new managerial practices is low, even compared to other Baltic and Eastern European countries (Figure 10). Latvia needs stronger innovation in order to ensure productivity growth in the long-term. The major challenge is to initiate a virtuous circle of stronger demand for innovation by Latvian firms and capacity of higher education and research institutions to offer innovative solutions. 


\section{The quality of research can be improved}

The excellence of academic research is a pre-requisite for the growth of industrial R\&D and research-intensive start-ups. While Latvia performs better than many other Eastern European countries in term of well-cited academic publications, it lags behind the OECD average (Figure 27).

The research funding and working conditions for researchers in Latvia are not conducive to research excellence. According to the OECD Main Science and Technology Indicators, R\&D expenditure by higher education and research institutions was $0.19 \%$ of GDP in 2016, which is low compared to the OECD average $(0.41 \%)$. Research positions are unstable due to the lack of a tenure system (OECD, 2016). Researchers are also often subject to overwork and receive uncompetitive salaries (European Commission, 2018d). Such unattractive working conditions make it difficult to address the scarcity of qualified researchers. The proportion of older-age researchers is high, and there are few researchers in the middle agegroups, implying that the research workforce will shrink fast (European Commission, 2018d).

The financial resources for research are thinly spread across a fragmented system of higher education and research institutions. In 2016, Latvia had 29 higher education institutions per million inhabitants, which is considerably more than in Estonia (19) or Lithuania (16) (Kulikovskis et al., 2017). Research institutions have been consolidated after 2014 mostly through more focused allocation of base funding and EU funds to larger institutions and those that performed well in the 2014 Research Assessment Exercise (Kulikovskis et al., 2017). However, the consolidation happened mostly at the level of administration: while smaller institutions are now managed as sub-sections of larger better-performing institutions, their facilities were not shut down and researchers did not relocate (Kulikovskis et al., 2017). The government envisages strengthening the sharing of research facilities and collaboration between consolidated research institutions. While such efforts are welcome, the government should consider further consolidation of research institutions, should the forthcoming Research Assessment Exercise (expected in 2020) find that some institutions are performing poorly. Financial resources saved from such consolidation could be reallocated to improve the working conditions of researchers.

Figure 27. The quality of academic research can be improved

Percentage of publications included among the world's 10\% most cited, 2015

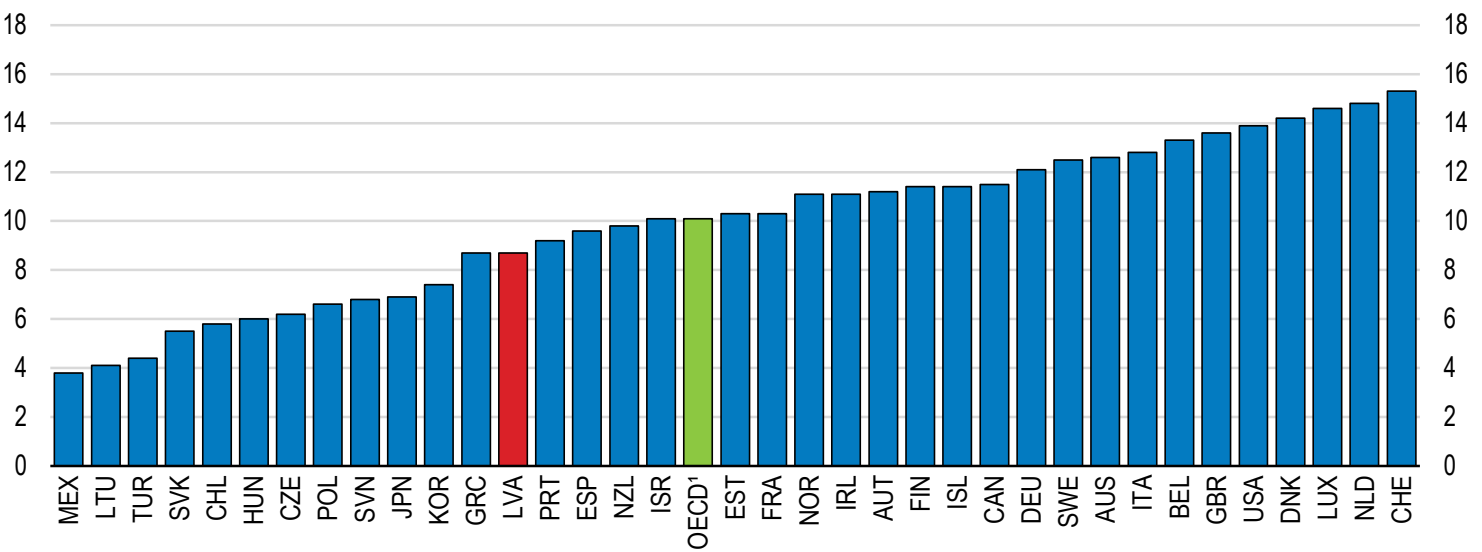

1. Unweighted average of available countries.

Source: OECD Science, Technology and Industry Scoreboard 2017.

StatLink Aiाs https://doi.org/10.1787/888933927117 
Figure 28. The research workforce is small

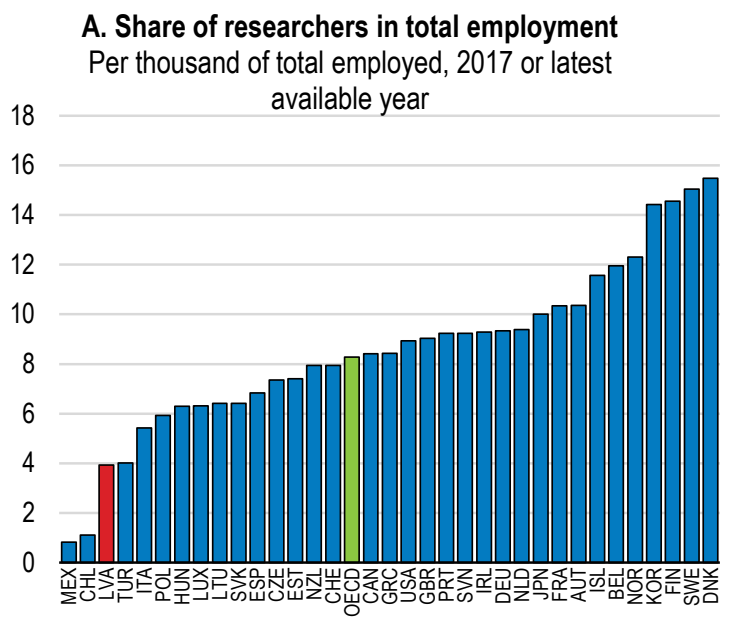

\section{B. New doctoral graduates}

Per thousand population aged 25-34, 2016

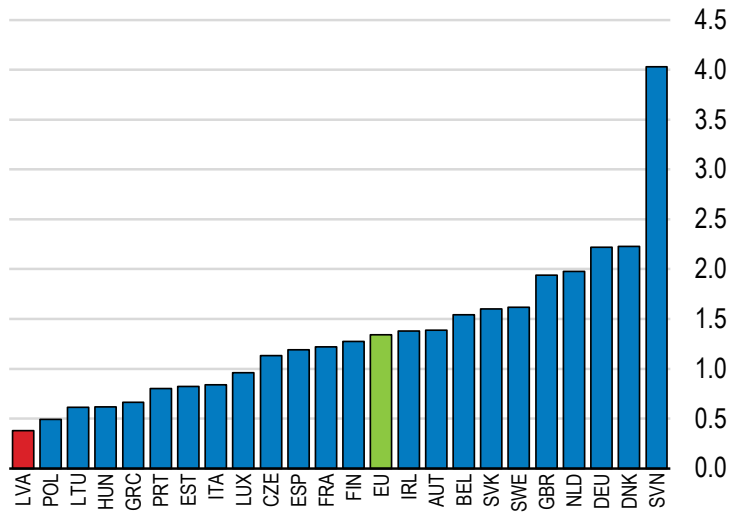

Source: OECD Main Science and Technology Indicators database; European Commission, Research and Innovation Observatory - Horizon 2020 Policy Support Facility, https://rio.jrc.ec.europa.eu/en/stats.

StatLink त्राज़ https://doi.org/10.1787/888933927136

The quality of research can also be improved by international collaboration. However, only $17 \%$ of academic publications in Latvia were the fruit of international collaboration in 2015, a share that is considerably lower than in other Baltic or Eastern European countries (Figure 29). International exchange of scholars and researchers in Latvia is coordinated by the State Education Development Agency (SEDA). The SEDA has granted scholarships to students and researchers from non-EU countries that concluded bilateral agreements on cooperation in education and science with Latvia. However, strict Latvian-language proficiency requirements for some occupations, including in higher education, can hinder international academic exchanges. As an example, limited Latvian language skills have delayed the appointment of rectors in at least two higher education institutions where teaching has been in English for almost two years and resulted in the resignation of one of them.

Figure 29. International collaboration in research is limited

International scientific collaboration, \% of domestically authored documents, 2015

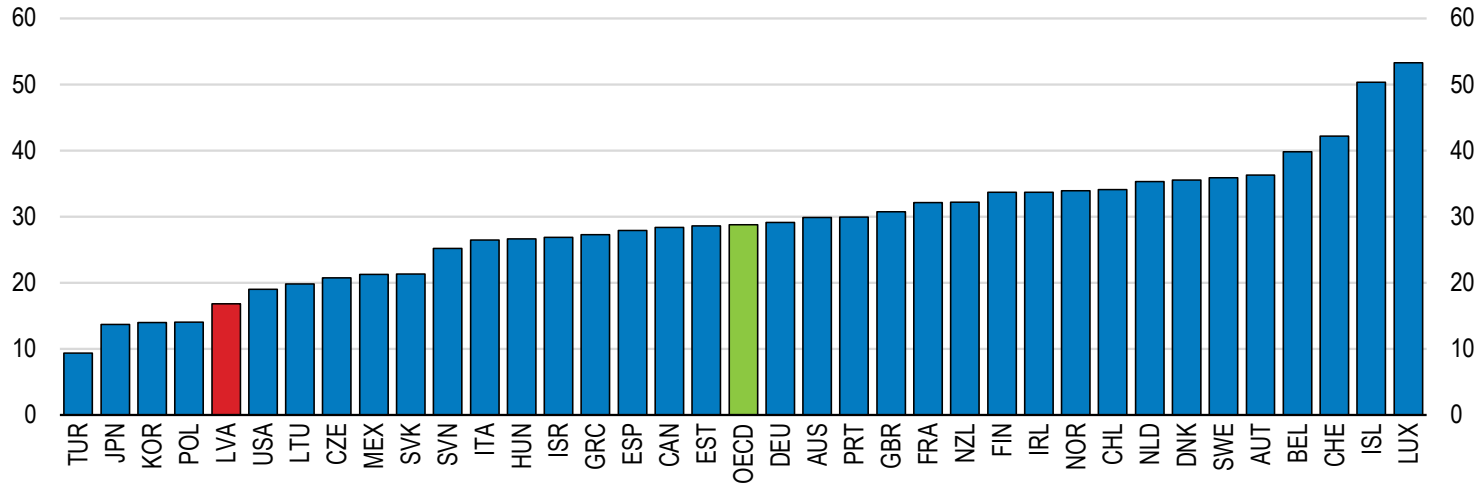

Note: International collaboration is defined as the number of domestically authored publications incorporating institutional affiliations of other countries or economies, expressed as a percentage of all publications attributed to authors with an affiliation in the reference economy. This includes a relatively small proportion of documents by single authors with affiliations in different economies.

Source: OECD Science, Technology and Industry Scoreboard 2017.

StatLink 제으 https://doi.org/10.1787/888933927155 


\section{Enhancing knowledge transfer}

Collaboration with higher education and research institutions could improve the innovation capabilities of Latvian firms through transfer of new technologies. With digitalisation, this is likely to become even more important (OECD, 2019c). Yet, the share of SMEs engaging in such collaboration in Latvia is low compared to many other OECD countries, including its Baltic or Eastern European peers (Figure 30).

The new higher education financing system currently under implementation rewards universities engaging in research collaboration with firms, by reallocating more funding to them. EU funded measures also support the training of academic personnel in firms. However, until now, universities put a large weight on academic publications in career evaluation and have not credited research collaboration with the industrial sector as much (European Commission, 2018d). It may take some time before universities adjust their career evaluation systems to the new financial incentives. Meanwhile, this holds back mobility of researchers between universities and firms, which is an important channel of knowledge transfer (OECD, 2019c). Only a few universities, for instance Riga Technical University, are actively exchanging personnel with firms.

Simplifying the administrative procedures can facilitate research collaboration. The government plans to develop methodological guidelines for knowledge transfer processes and to provide training in these to research institutions.

Figure 30. There is little collaboration between SMEs and research institutions

Share of SMEs collaborating on innovation with higher education or research institutions, 2012-14

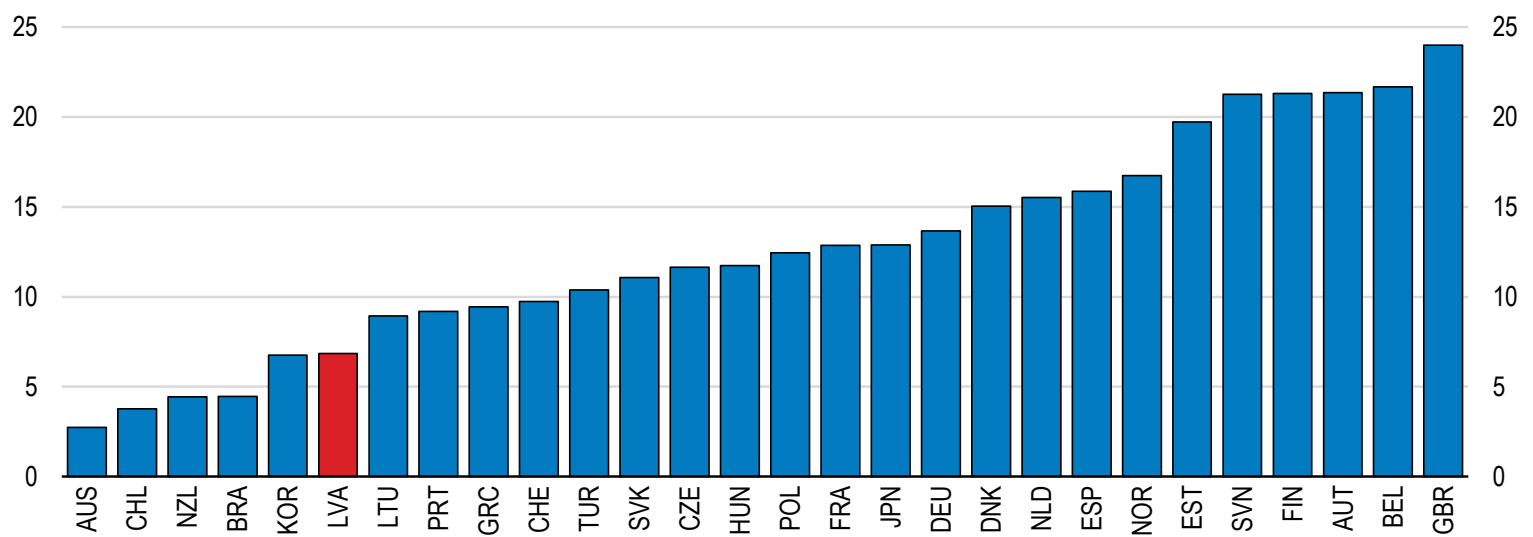

Note: As a percentage of product and/or process-innovating SMEs. Source: OECD Science, Technology and Industry Scoreboard 2017.

StatLink Ants https://doi.org/10.1787/888933927174

\section{Stimulating $R \& D$ demand for business innovation}

Latvian firms are oriented toward incremental process innovation that does not involve R\&D or patent application (Muizniece and Cepilovs, 2017), and consequently may not consider research inputs to be relevant for their success. Also, firms in medium to low technology manufacturing and services, which are dominant in Latvia, often seek to solve specific technical problems through case-by-case interaction with university researchers, also referred to as technology extension services, rather than exploring novel inventions through formal research collaboration (Johnston and Huggins, 2017). Technology 
extension services are effective in supporting knowledge transfer to those types of firms, and can also be a first step toward more formal research collaboration (OECD, 2019c). The government expanded the innovation voucher scheme that finances firms' purchase of technology extension services. It also reorganised the Technology Transfer Offices (TTOs) in universities into a one-stop shop in the Latvian Investment and Development Agency (LIDA), in line with recent efforts by OECD countries to enhance efficiency of technology transfer (Box 3).

Small firms often need to be nudged to participate in research collaboration. Evidence from OECD countries indicates that campaigns to raise awareness on the benefits of innovation encourage small firms to participate in support measures for formal research collaboration (Lanahan and Feldman, 2015). For small firms, informal interactions with researchers through events like technology fairs are often as effective as a channel of knowledge transfer as formal research collaboration (OECD, 2019c). The government has been implementing the Innovation Motivation Program, which organises numerous networking events and promotion of innovative entrepreneurship especially among the youth. Such efforts should be continued until a significant improvement in the share of SMEs engaging in innovation and research collaboration is observed.

\section{Box 3. Trends in knowledge transfer policies across OECD countries}

The policy instruments for promoting knowledge transfer from higher education and research institutions to industry have been evolving, responding to new demand for industry-science research collaborations brought about partly by the digitalisation that increased the complexity of innovation (OECD, 2019c).

\section{“Off-campus" technology transfer offices (TTOs) and intermediary organisations}

New types of regional or sectoral TTOs that pool services of traditional TTOs at each university and research institutions are being created, to improve efficiency and quality of technology transfer. Latvia created a one-stop shop at the Latvian Investment and Development Agency (LIDA), which dispatches groups of researchers stationed in universities across the country (technology scout teams) to firms to help them deal with technological issues or commercialise their innovation. France created a total of 14 "transfer acceleration companies" (SATTs) across the country, each pooling specific services of TTOs in the region. The role of specialised research institutions dedicated to strengthening the innovation capabilities of SMEs is also increasing. For instance, the Canadian Technology Access Centres (TAC) transfer talent, expertise and technology from affiliated technical universities or colleges to SMEs. A network of 30 TACs is coordinated by a Canadian college that receives a public grant (Innovation, Science and Economic Development Canada, 2019).

\section{From knowledge transfer to knowledge co-creation}

Joint research laboratories where research institutions and firms share resources and risks to engage in long-term research agendas are being developed with the support of public funds. Such a scheme builds closer and lasting research collaboration compared to a simple technology transfer, as it involves setting up joint infrastructure and mixed teams. Latvia hosts 6 Competence Centres, EU-funded consortiums between firms and research institutions that promote joint innovation in fields of Smart Specialisation Strategy. The United Kingdom hosts 10 Catapult centres, where firms, scientists and engineers work on late-stage R\&D in strategic industries and technologies (Digital Catapult, 2019). Each 
Catapult has several physical centres spread across the UK. Portugal recently launched collaborative laboratories (CoLAB), mainly privately funded organisations that integrate research activities by research institutions and firms, and focus on market-driven research and professional R\&D services for industry.

\section{Attracting foreign research institutions for knowledge transfer}

Some countries have developed dedicated programmes to attract world-class foreign research institutions to establish new research centres locally in collaboration with national universities and firms. Chile launched in 2009 the International Centres of Excellence programme, providing public funding to 8 international universities and research institutions including the University of California, Davis and Germany's Fraunhofer Institute, to create local $R \& D$ centres that collaborate with Chilean firms (Ministry of Economy, Development and Tourism of Chile, 2019). Some of the centres have developed new intermediary institutions to promote technology transfer.

\section{Enhancing the efficiency of support measures}

The implementation of support measures for innovation and research collaboration are fragmented across several agencies. From 2014, the measures funded by EU funds are administered by the Central Finance and Contracting Agency (CFCA) affiliated to the Ministry of Finance, separately from the measure funded by the national budget. This provided a one stop shop to applicants for EU funded measures, contributing to a smooth absorption of EU funds. However, it also led to duplication of the capacity developed by the CFCA for this new task and those of agencies affiliated to the Ministry of Education and Science and the Ministry of Economics, which have been implementing innovation support until then. This also complicated the implementation of support measures, for instance due to agencies competing for the reviewers needed for the selection and evaluation of projects that receive support (European Commission, 2018b). Considering the small size of research community in Latvia, the implementation of innovation support should be consolidated into one agency to maximise the efficiency of policy resources and synergies across various support measures.

\section{Using EU funds more effectively to promote productivity}

\section{Ensuring the continuity of the most effective EU-funded policy measures}

Latvia is one of the largest recipients of EU funds (Figure 31). A wide range of important policy instruments aimed at facilitating access to credit, improving skills and employment and boosting innovation rely heavily on EU funds. Some of the most essential activities have been disrupted in the past during the switchover between EU Funds programming periods, because of slower disbursement of EU funds. For instance, the funding for developing new curricula for vocational education was discontinued temporarily in 2016 (OECD, 2017a). Gross R\&D expenditure dropped from $0.63 \%$ of GDP in 2015 to $0.44 \%$ in 2016, as about $50 \%$ of Latvia's business-based R\&D and $44 \%$ of higher education R\&D expenditure were financed by EU funds in 2015 (OECD, 2017c).

As it is unclear how the availability of EU funds will develop in the long run, the government must ensure the continuity of essential policy measures by gradually reducing their dependence on the EU budget. This requires identifying the most effective measures currently financed by EU funds and planning for national financing of these programmes 
beyond the current EU budgetary cycle. For instance, $75 \%$ of active labour market policies (ALMPs) are financed by EU funds. The recent assessment by the OECD (OECD, 2019b) on the effectiveness of various types of ALMP measures should be used to identify the measures to receive stable funding. Support measures to promote innovation and knowledge transfer that are mainly financed by EU funds should also be evaluated and streamlined. Finally, the long-term fiscal strategy should anticipate a possible need for additional revenues from 2022 onwards.

The government should also seek a larger role of the private sector and the financial market in financing productivity-enhancing activities like risk financing, vocational education and training (VET), and joint innovation activities between firms and research institutions. For instance, the public financial institution Altum plans to diversify financing sources for its public loan programmes, which currently rely heavily on EU funds. VET curricula reforms and work-based learning should be financed by employers to a larger extent, for instance, through their contributions to employer associations, as in Germany and Austria, given that they benefit from more effective VET providing highly relevant skills. The government should also foster profit-based research collaborations.

Figure 31. Latvia is one of the largest recipients of EU funds

EU Structural Funds, 2014-2020, as \% of 2017 GDP

LUX DNK NLD AUT IRL SWE GBR BEL DEU FIN FRA ITA ESP SVN GRC PRT CZE EST LTU SVK POL LVA HUN

Note: EU funds are European Regional Development Fund, European Social Fund, Cohesion Fund, and Youth Employment Initiative for the 2014-2020 period, allocated after the adoption of the Partnership Agreements. They do not include country-wise allocation of interregional co-operation, urban innovative actions and technical assistance.

Source: European Structural and Investment Funds database.

StatLink 제내 https://doi.org/10.1787/888933927193

\section{Improving access to EU funds}

EU funds should be allocated toward areas where the highest needs and largest gains are foreseen. The European Regional Development Fund (ERDF) provides co-financing to investment projects proposed by Latvian firms, offering them an opportunity to increase investment, scale up their production and boost productivity (Box 4). The positive effect of the ERDF on productivity is largest among firms with an initially lower productivity level. This suggests that the effectiveness of the ERDF in boosting productivity can be enhanced by strengthening access to co-financing for small young firms with a large potential for productivity catch up.

However, the ERDF co-financing tends to be awarded to larger and more productive firms, which can be expected to have better access to credit (Box 4). The application process for 
EU fund co-financing involves complex procedures and the management of EU funded projects is subject to onerous compliance costs (OECD, 2018e). Indeed, firms sometimes hire professional consultants to write the applications, which implies substantial upfront costs. Such administrative burdens prevent smaller and less productive firms from accessing the ERDF co-financing.

Some measures are in place to facilitate the access by smaller firms to EU fund cofinancing. The Competence Centres and the Latvian Investment and Development Agency (LIDA) provide technical support and consultation services to SMEs for their application. However, they do not actually process the applications procedures for the SMEs. The six Competence Centres are mostly located in Riga, making it difficult for firms in rural areas to access such services. Access to EU funds can be further improved by simplifying application procedures and streamlining regulations set by authorities on the management of EU-funded projects. Basing the selection process more on an interaction with potential applicants, for instance through face-to-face interview as envisaged in Poland (OECD, 2018f), would increase the chances of small, young and innovative firms to receive cofinancing.

\section{Box 4. The effect of EU funds on the performance of Latvian firms}

Joint research by the OECD and the Bank of Latvia (Benkovskis et al., 2018) investigates empirically the effect of launching a project co-financed by the European Regional Development Fund (ERDF) on the performance of Latvian firms. It finds that launching an ERDF co-financed project results in the following in the third year of the launch:

- A $28 \%$ increase in the capital stock per employee

- A $17 \%$ increase in the number of employees

- A $20 \%$ increase in the turnover

- A $12 \%$ improvement in labour productivity

The observed surges in capital stock and employment are not surprising as the ERDF finances investment and firm's capacity to expand employment is an important criterion for the selection of projects. The improvement in the productivity is highly heterogeneous across ERDF recipients: it is significantly larger for recipients with an initially low productivity level.

The research also shows that firms that are more likely to obtain the ERDF co-financing are larger and more productive to begin with. Furthermore, hiring a manager who previously worked in a firm that acquired the ERDF co-financing increases the possibility of the current employer to obtain the co-financing. This indicates that the application to and the management of EU fund projects involve significant fixed costs that only larger and more productive firms can bear. Such costs are generated by administrative procedures that require specific knowledge and skills.

\section{Establishing an effective productivity board}

Policies that directly or indirectly affect productivity growth touch upon a wide range of areas and are administered by multiple public actors, making their coordination challenging. Furthermore, productivity-enhancing policies may lead to losses for some 
influential groups and thus face strong political headwinds (Banks, 2015). To address such difficulties, many OECD countries have established institutions that analyse the productivity challenges and provide a comprehensive strategy for productivity-enhancing reforms. Those institutions can improve policy coordination and advocate the importance of reforms to a wide audience (Renda and Dougherty, 2017). EU countries, particularly euro area countries, were advised by the Council of the European Union to establish a national productivity board, as the improvement in productivity was deemed essential for the reduction of current account imbalances and adjustment to country-specific shocks within the monetary union (Council of the European Union, 2016).

While there is not an optimal approach to establish a productivity board, the institution tends to be more effective when it is backed by a strong political commitment (as in Mexico or Ireland), is endowed with sufficient resources to conduct high quality research, and is engaging with stakeholders (Renda and Dougherty, 2017). The effectiveness of a productivity board is particularly high when it is directly involved in the policy-making processes bearing on productive performance, or is in a position to directly influence decision-making in those areas (Banks, 2015).

Two organisations in Latvia may take on the task of the productivity board: Latvia's Forum for Productivity, Effectiveness, Development, and Competitiveness (LV PEAK) and the Competitiveness and Sustainability Tripartite Co-operation Sub-Council (KITSA). The LV PEAK, established in May 2018 by the University of Latvia and led by academics and experts, conducts independent analysis on productivity issues and formulates policy recommendations. It has a co-operation agreement with the Ministry of Economics, but its funding is limited. The KITSA, established also in May 2018 under the National Tripartite Council, is comprised of representatives of relevant ministries, the employers' association (the LDDK) and the Free Trade Union Confederation of Latvia (LBAS), and fosters cooperation in important policy areas for competitiveness, such as digitalisation. The experiences from other OECD countries suggest that the government should consider merging the LV PEAK and the KITSA into one institution that boasts high research capabilities and strong involvement in policy-making. This would allow the productivity board to produce high-quality policy recommendations and enjoy strong political support. 
Policy recommendations for stronger productivity growth

(Key policy recommendations are bolded)

Fighting Informality

- Continue the engagement of social partners in the fight against informality through sectoral agreements.

- Offer sufficiently high wages to attract qualified personnel in law enforcement agencies.

- Phase out the microenterprise tax regime.

Improving the allocation of capital

- Allow creditors to initiate restructuring and introduce early warning mechanisms of financial distress.

- Improve the quality and speed of judgement through training and specialisation of judicial staff.

- Ensure the accountability of judges, including by extending the deadlines for dealing with disciplinary cases.

Enhancing competition

- Develop detailed guidelines for the review of the rationale for state ownership and apply them more rigorously.

- Strengthen the authority of the Competition Council to intervene against anticompetitive behaviour by state-owned and municipal enterprises.

- Extend the monitoring framework for state-owned enterprises to large commercially-oriented municipality-owned enterprises.

- Provide the Competition Council with sufficient funds to hire qualified experts.

Strengthening skills

- Promote joint training offers involving several firms.

- Consider setting up mechanisms that help small firms handle all the logistics and administrative procedures to offer work-based learning.

- Raise awareness of the benefits of work-based learning by conducting rigorous cost-benefit analysis and advertising its findings.

- Use the Vocational Education Competence Centres (VECCs) as a platform to coordinate and ensure the quality of vocational and adult training.

- Introduce means-tested financial assistance for tertiary students

- Implement as early as possible the planned financial support for firms providing training to employees with stronger financing for the low skilled.

- Hire more counsellors in Public Employment Services. 
- Evaluate EU funded training to identify the most effective programmes

- Plan for the financing of EU funded training beyond the current EU budgetary cycle, if necessary from national sources.

Strengthening innovation and knowledge transfer

- Promote sharing of resources of universities and research institutions.

- Improve wages, working conditions and career prospects for researchers in public institutions and provide stronger incentives to collaborate with industry.

- Consolidate the implementation of innovation support into one agency.

Using EU funds more effectively to promote productivity

- Simplify the application procedure for EU funds and streamline the regulations on the management of EU-funded projects.

Establishing an effective pro-productivity institution

- Establish a productivity board with a high research capacity and strong involvement in the policy-making process. 


\section{References}

Adalet McGowan, M., D. Andrews and V. Millot (2017), "Insolvency Regimes, Technology Diffusion and Productivity Growth : Evidence from Firms in OECD Countries", OECD Econonomics Department Working Papers, No. 1425, OECD Publishing, Paris. http://dx.doi.org/10.1787/36600267-en

Adalet McGowan, M. and D. Andrews (2018), "Design of insolvency regimes across countries", OECD Economics Department Working Papers, No. 1504, OECD Publishing, Paris. http://dx.doi.org/10.1787/d44dc56f-en

Aghion, P. et al. (2005) "Competition and Innovation: An Inverted-U Relationship", The Quarterly Journal of Economics, vol. 120, pp. 701-728.

Andrews, D., G. Nicoletti and C. Timiliotis (2018), "Digital technology diffusion: A matter of capabilities, incentives or both?", OECD Economics Department Working Papers, No. 1476, OECD Publishing, Paris, https://doi.org/10.1787/7c542c16-en.

Andrews, D., C. Criscuolo and P. Gal (2016), "The Best versus the Rest: The Global Productivity Slowdown, Divergence across Firms and the Role of Public Policy", OECD Productivity Working Papers, No. 5, OECD Publishing, Paris, https://doi.org/10.1787/63629cc9-en.

Arnold, J., G. Nicoletti and S. Scarpetta (2011), "Regulation, resource reallocation and productivity growth", European Investment Bank Papers, vol. 16, pp. 90-115.

Banerjee, R.N., Gambacorta, L. and E. Sette (2017) “The real effects of relationship lending” Bank for International Settlements Working Papers No. 662.

Bank of Latvia (2017), Financial Stability Report 2017, Riga.

Bank of Latvia (2018), Financial Stability Report 2018, Riga.

Banks, G. (2015), "Institutions to promote pro-productivity policies: Logic and lessons", OECD Productivity Working Papers, No. 1, OECD Publishing, Paris. https://doi.org/10.1787/5jrql2tsvh41en.

Beck, T., Degryse, H., De Haas and N.R. van Horen (2015) "When Arm's Length Is Too Far. Relationship Banking over the Credit Cycle", SRC Discussion Paper No. 33.

Berlingieri, G.et al. (2019), "Last but not least: laggard firms, technology diffusion and its structural and policy Determinants", OECD Science, Technology and Industry Working Papers, OECD Publishing, Paris. Forthcoming.

Berlingieri, G. et al. (2017), "The Multiprod project: A comprehensive overview”, OECD Science, Technology and Industry Working Papers, 2017/04, OECD Publishing, Paris. http://dx.doi.org/10.1787/2069b6a3-en

Benkovskis, K., O. Tkacevs and N. Yashiro (2019), "The role of resource allocation in Latvia's productivity", OECD Economics Department Working Papers, OECD Publishing, Paris. Forthcoming.

Benkovskis, K., O. Tkacevs and N. Yashiro (2018), "Do EU Funds boost productivity and employment?: Firm level analysis for Latvia", OECD Economics Department Working Papers, No. 1525, OECD Publishing, Paris. https://doi.org/10.1787/98e0a368-en.

Benkovskis, K. (2015), "Misallocation of Resources in Latvia: Did Anything Change During the Crisis?", Working Papers 2015/05, The Bank of Latvia. Riga. 
Blanchard, O., M. Griffiths. and B. Gruss, (2013), Boom, Bust, Recovery: Forensics of the Latvia Crisis, Brookings Papers on Economic Activity, Economic Studies Program, vol. 44, pp 325-388.

Borowiecki, M. and C. Paunov (2018), "How is research policy across the OECD organised?: Insights from a new policy database", OECD Science, Technology and Industry Policy Papers, No. 55, OECD Publishing, Paris, https://doi.org/10.1787/235c9806-en.

European Commission for the Efficiency of Justice (CEPEJ) (2018), Evaluation of the Latvian Judicial System, Brussels. Retrieved from: http://www.ta.gov.lv/UserFiles/Faili/CEPEJ_Evaluation_Report_Latvia_Final_En.pdf

Competition Council of Latvia (2018), Annual Report 2017, Riga.

Council of the European Union (2016), Council Recommendation of 20 September 2016 on the establishment of National Productivity Boards, OJC 349, 24.9.2016, 1-4.

Digital Catapult (2019), "Digital Catapult", Country policy case study contribution to the OECD TIP Digital and Open Innovation project.

Distinguin, I., C. Rugemintwari and R. Tacneng (2016), “Can Informal Firms Hurt Registered SMEs' Access to Credit?" World Development, vol. 84, pp. 18-40.

Égert, B. and A. Vindics (2019), "Mark-ups and product market regulation in OECD countries: what do the data whisper?" OECD Economics Department Working Paper, forthcoming.

European Central Bank (2018), ECB Bank Lending Survey, Brussels.

European Commission (2018a), Digital Economy and Society Index (DESI) 2018 Country Report Latvia, Brussels. Retrieved from: https://ec.europa.eu/digital-single-market/en/scoreboard/latvia

European Commission (2018b), Country Report Latvia 2018, Brussels. Retrieved from: https://ec.europa.eu/info/sites/info/files/2018-european-semester-country-report-latvia-en 1.pdf

European Commission (2018c), 2018 EU Justice Scoreboard, Brussels. Retrieved from: https://ec.europa.eu/info/policies/justice-and-fundamental-rights/effective-justice/eu-justicescoreboard en

European Commission (2018d) The Latvian Research Funding System, European Commission Directorate-General for Research and Innovation, Brussels. Retrieved from:

https://rio.jrc.ec.europa.eu/en/library/specific-support-latvia-final-report-\%E2\%80\%93-latvianresearch-funding-system

Eurofound (2017a), United Kingdom: Rescue procedures in insolvency, https://www.eurofound.europa.eu/observatories/emcc/erm/legislation/united-kingdom-rescueprocedures-in-insolvency

Eurofound (2017b), Living and working in Latvia, https://www.eurofound.europa.eu/country/latvia

European Investment Bank (2018) EIB Group Survey on Investment and Investment Finance Country Overview: Latvia, European Investment Bank (EIB). Retrieved from: https://www.eib.org/en/infocentre/publications/all/econ-eibis-2018-latvia.htm

Fazekas, M. and S. Field (2013a), A Skills beyond School Review of Germany, OECD Reviews of Vocational Education and Training, OECD Publishing. http://dx.doi.org/10.1787/9789264202146-en

Fazekas, M. and S. Field (2013b), A Skills beyond School Review of Switzerland, OECD Reviews of Vocational Education and Training, OECD Publishing. http://dx.doi.org/10.1787/9789264062665-en 
Garicano, L., C. Lelarge, and J. Van Reenen (2016) "Firm Size Distortions and the Productivity Distribution: Evidence from France”, American Economic Review, vol.106, pp. 3439-3479.

Hazak, A. (2009) "Companies' financial decisions under the distributed profit taxation regime of Estonia", Emerging Markets Finance and Trade, vol. 45, pp. 4-12.

Havrylchyk, O. (2012), "The effect of foreign bank presence on firm entry and exit in transition economies", Journal of Banking and Finance, vol. 36, pp. 1710-1721.

Havrylchyk, O. et al. (2012), "Foreign bank entry and credit allocation in emerging markets", Journal of Banking and Finance, vol. 36, pp. 2949-2959.

Innovation, Science and Economic Development Canada (2019), "The Technology Access Centres (TAC) programme in Canada", Case study produced for the OECD TIP Knowledge Transfer project.

Jacobs, B. et al. (2017), Latvia tax review. World Bank Group, Washington, D.C. Retrieved from: http://documents.worldbank.org/curated/en/587291508511990249/Latvia-tax-review

Johnston, A. and R. Huggins (2017), "University-industry links and the determinants of their spatial scope: A study of the knowledge intensive business services sector", Papers in Regional Science, Vol. 96, pp.247-260.

Kalvane, I. (2015) "Business Model Choice for Latvian Public Employment Service: What is the Best for Labour Force Competitiveness?" Procedia - Social and Behavioral Sciences, vol. 213, pp. 99-104.

Kuczera, M. (2017), "Striking the right balance: Costs and benefits of apprenticeship", OECD Education Working Papers, No. 153, OECD Publishing, Paris. http://dx.doi.org/10.1787/995fff01-en

Kulikovskis, G, D., Petraitytè, and B. Stamenov (2018), RIO Country Report 2017: Latvia, Publications Office of the European Union, Luxembourg.

Kulikovskis, G, D., Petraitytė, and B. Stamenov (2017), RIO Country Report 2016: Latvia, Publications Office of the European Union, Luxembourg.

Lanahan, L. and M.P. Feldman (2015), "Multilevel innovation policy mix: A closer look at state policies that augment the federal SBIR program", Research Policy, vol. 44, pp. 1387-1402.

Masso, J., Meriküll, J. and P. Vahter (2013) "Shift from gross profit taxation to distributed profit taxation: Are there effects on firms?" Journal of Comparative Economics, vol. 41, pp. 1092-1105.

Mazure, G. (2011), "Development of Credit Unions as Instrument for Expansion of Crediting", Proceedings of the Fifth International Scientific Conference "Rural Development 2011", vol5, pp.136-143.

Melitz, M. J. and S. Polanec (2015), "Dynamic Olley-Pakes productivity decomposition with entry and exit", The RAND Journal of Economics, vol.46, pp. 362-375.

Midrigan, V. and D. Xu (2014), "Finance and Misallocation: Evidence from Plant-Level Data," American Economic Review, vol.104, pp.422-458.

Ministry of Economics (2018) Informative Report on Medium and Long-term Labour market forecasts, Riga. Retrieved from:

https://www.em.gov.lv/en/economic development/informative report_on medium and long term 1 abour_market_forecasts/

Ministry of Economy, Development and Tourism of Chile (2019), "Public policy to promote technology transfer in Chile: Licensing and technology transfer offices and technology transfer hubs", case study produced for the OECD TIP Knowledge Transfer project. 
Ministry of Education and Science (2019). Informative Report On Implementing and Developing the System of Work-Based Learning to Increase the Proportion of Work-Based Learning in Vocational Education, reviewed at the Cabinet of Ministers on April 2, 2019. Retrieved from: http://tap.mk.gov.lv/lv/mk/tap/?pid=40470715

Moll, B. (2014), "Productivity Losses from Financial Frictions: can self-financing undo Capital Misallocation?", American Economic Review, Vol.104, pp.3186-3221.

Muizniece,L. and A. Cepilovs (2017), "Supporting university technology transfer-struggles and barriers in Latvia" Ekonomska misao i praksa, vol.1, pp. 321-342.

Musset, P., et al. (2013), Skills beyond School Review of Austria, OECD Reviews of Vocational Education and Training, OECD Publishing. Paris. http://dx.doi.org/10.1787/9789264200418-en

OECD (2019a), Financing SMEs and Entrepreneurs 2019: An OECD Scoreboard, OECD Publishing, Paris, https://doi.org/10.1787/fin_sme ent-2019-en.

OECD (2019b), Evaluating Latvia's Active Labour Market Policies: Connecting People with Jobs, OECD Publishing, Paris, https://doi.org/10.1787/6037200a-en.

OECD (2019c), University-Industry Collaboration: New Evidence and Policy Options, OECD Publishing, Paris, https://doi.org/10.1787/e9c1e648-en .

OECD (2018a), Access to Justice for Business and Inclusive Growth in Latvia, OECD Publishing, Paris, https://doi.org/10.1787/9789264303416-en.

OECD (2018b), "Competition Law and State-Owned Enterprises: Contribution from Latvia", Global Forum on Competition, DAF/COMP/GF/WD(2018)49

OECD (2018c), Education at a Glance 2018: OECD Indicators, OECD Publishing, Paris, https://doi.org/10.1787/eag-2018-en.

OECD (2018d), OECD Economic Surveys: Switzerland 2018, OECD Publishing, Paris.

OECD (2018e), OECD Economic Surveys: European Union 2018, OECD Publishing, Paris.

OECD (2018f), OECD Economic Surveys: Poland 2018, OECD Publishing, Paris.

OECD (2017a), OECD Economic Surveys: Latvia 2017, OECD Publishing, Paris. http://dx.doi.org/10.1787/eco surveys-lva-2017-en

OECD (2017b), Corporate Governance in Latvia, OECD Publishing, Paris. http://dx.doi.org/10.1787/9789264268180-en

OECD (2017c), OECD Science, Technology and Industry Scoreboard 2017: The digital transformation, OECD Publishing, Paris, https://doi.org/10.1787/9789264268821-en.

OECD (2017d), Starting Strong V: Transitions from Early Childhood Education and Care to Primary Education, OECD Publishing, Paris, https://doi.org/10.1787/9789264276253-en.

OECD (2017e), Financial Incentives for Steering Education and Training, Getting Skills Right, OECD Publishing, Paris, https://doi.org/10.1787/9789264272415-en.

OECD (2016), Education in Latvia, Reviews of National Policies for Education, OECD Publishing, Paris, https://doi.org/10.1787/9789264250628-en.

OECD (2015a), The Future of Productivity, OECD Publishing, Paris.

OECD (2015b), OECD Economic Surveys: Latvia 2015, OECD Publishing, Paris. 
OECD (2010), Learning for Jobs, OECD Reviews of Vocational Education and Training, OECD Publishing, Paris, https://doi.org/10.1787/9789264087460-en.

OECD (2009), OECD Economic Survey, Estonia 2009, OECD Publishing, Paris.

OECD/The European Commission/ETF (2014), SME Policy Index: The Mediterranean Middle East and North Africa 2014: Implementation of the Small Business Act for Europe, OECD Publishing, Paris. https://doi.org/10.1787/9789264218413-en.

Olley, G. S. and A. Pakes (1996), "The Dynamics of Productivity in the Telecommunications Equipment Industry", Econometrica, vol. 64, pp. 1263-1297.

Papa, J., Rehill, L., and B. O'Connor "Patterns of Firm Level Productivity in Ireland", $O E C D$ Productivity Working Papers, 2018-15, OECD Publishing, Paris. https://doi.org/10.1787/1a04730den.

Pavcnik, N. (2002), "Trade Liberalization, Exit, and Productivity Improvements: Evidence from Chilean Plants", Review of Economic Studies, vol.69, 245-76.

Poulsen, S. and C. Eberhardt (2016), "Approaching Apprenticeship Systems from a European Perspective", Discussion Papers, No. 171, BIBB, Bonn. Retrieved from: www.bibb.de/veroeffentlichungen/en/publication/show/id/7987.

Praxis Center for Policy Studies (2010), Impact of Non-taxable Retained Profits on Investments and Economic Development (Ettevõtete jaotamata kasumi mittemaksustamise mõju investeeringutele ja majandusarengule), Talinn. http://www.praxis.ee/en/works/impact-of-non-taxable-retained-profits/

Renda, A. and Dougherty, S., "Pro-Productivity Institutions: Learning From National Experience", OECD Productivity Working Papers, 2017-07, OECD Publishing, Paris. https://doi.org/10.1787/d1615666-en.

Rupeika-Apoga, R. and I. Solovjova (2017), “Access to Finance for Latvian SMEs” European Research Studies Journal, vol. 20, pp. 57-68.

Sauka, A. and T. Putniņš (2019), Shadow Economy Index for the Baltic Countries 2009-2018, Stockholm School of Economics at Riga, Riga.

Staehr, K. (2014), “Corporate Income Taxation in Estonia. Is It Time to Abandon Dividend Taxation?", TUTECON Research Brief, No. RB-2014/1, Tallinn University of Technology, Department of Economics and Finance. Tallinn.

Stein, J. (2002), "Information Production and Capital Allocation: Decentralized Versus Hierarchical Firms", Journal of Finance, vol. 57, pp. 1891-1921. 